Lucyna Błażejczyk-Majka, Jan Miłosz

(Uniwersytet im. Adama Mickiewicza w Poznaniu)

\title{
Występowanie chorób zakaźnych w Wielkopolsce w latach 1945-1953 \\ w świetle dokumentów Archiwum Państwowego w Poznaniu
}

\author{
Zaraza - Głód - Wojna - \\ trzej jeźdźcy APOLALIPSY \\ a za nimi na siwym koniu \\ jedzie - SMIERĆ
}

\section{Wstęp}

Każda wojna, zwłaszcza jeżeli jest tak totalna, jak II wojna światowa, niesie ze sobą bezmiar cierpień, zniszczeń i śmierci. Jednak nawet jej szczęśliwy dla narodów koniec, nie pozwala o niej zapomnieć. Pozostałości w postaci ruin, cmentarzy i milionów bezdomnych jeszcze długo po zakończeniu działań militarnych o wojnie przypominają. Obok strat materialnych piętnem wojny jest także osłabienie tej części populacji, której udało się ją przeżyć. Ludność, bez względu na to, czy należała do państw zwycięskich czy zwyciężonych, musiała zmierzyć się nie tylko z problemami związanymi z zabezpieczeniem sobie bytu, ale z chorobami, a nawet epidemiami.

Również w Wielkopolsce ostatni rok wojny i pierwsze miesiące pokoju rozpoczęły się pod znakiem ruchu wojsk i ludności cywilnej. W połowie stycznia 1945 r. operacja wiślańsko-odrzańska Armii Czerwonej w ciągu niespełna dwóch miesięcy przesunęła linię frontu o ponad pięćset $\mathrm{km}$ i była początkiem całego szeregu zmian, jakie w następnych latach miały miejsce na obszarze między Wisłą a Odrą ${ }^{2}$. Szybkość ofensywy czterech sowieckich

${ }^{1}$ F.F. Cartwright, M. Biddiss, Niewidoczny wróg - zarazy i historia, przekł. M. Wyrwas-Wiśniewska, Warszawa 2005.

${ }^{2}$ K. Stryjkowski, Poznań '45. Ostatni rok wojny i pierwszy rok odbudowy, Poznań 2013, s. 16-20. 
frontów działających na tym obszarze spowodowała, że jedynie część niemieckiej ludności cywilnej zdołała wykonać wydany w ostatnim momencie rozkaz Hitlera o ewakuacji. Część pociągów z niemieckimi uciekinierami wyjeżdżała $\mathrm{z}$ Poznania już $\mathrm{w}$ momencie wkraczania $\mathrm{w}$ granice miasta pierwszych oddziałów sowieckich, a ostatni z nich został doszczętnie zniszczony przez czołgi radzieckie przeprawiające się przez Wartę na południe od miasta w okolicach Lubonia.

W połowie 1945 r. rozpoczęły się także ruchy ludności cywilnej. Mieszkańcy tego terenu wracali z tułaczki wojennej. Przez Wielkopolskę przewożono repatriantów, którzy docelowo mieli osiedlić się na terenie ziem zachodnich. Wojska przemieszczały się z zachodu na wschód. Ludność niemiecka czekała w obozach tymczasowych na przesiedlenie. Jednocześnie funkcjonowały obozy dla żołnierzy niemieckich. Wszystkie wymienione grupy ludności egzystowały $\mathrm{w}$ atmosferze tymczasowości. Jednak oprócz poczucia niepewności jutra ludność zmagała się z niedożywieniem i niezaspokojeniem podstawowych warunków sanitarnych.

Władze państwowe zdawały sobie sprawę z zagrożeń epidemiologicznych, jakie wynikały ze wspomnianych ruchów wojsk i ludności związanych z zakończeniem wojny. Niemniej jednak skala zjawiska była tak wielka, że nie wszystkie zagrożenia chorobami zakaźnymi można było administracyjnie przewidzieć i opanować. W latach czterdziestych i pięćdziesiątych lekarze powiatowi przekazywali do Wydziału Zdrowia Urzędu Wojewódzkiego ${ }^{3}$ w Poznaniu cotygodniowe sprawozdania dotyczące zachorowalności na choroby zakaźnie i śmiertelności z nimi związanej. Celem pracy jest prezentacja liczbowych danych wykazywanych w tych raportach dla roku 1946. Wyniki tych analiz zostały porównane $z$ danymi $z$ analogicznych raportów generowanych w roku 1953. Co więcej, w pracy podjęto próbę wyjaśnienia większej liczby zachorowań na choroby zakaźnie w określonych obszarach Wielkopolski w szerszej perspektywie wydarzeń historycznych tego okresu.

Źródłem danych o charakterze ilościowym, dotyczących statystyk zachorowań i śmiertelności na choroby zakaźnie, były akta Wydziału Zdrowia Urzędu Wojewódzkiego Poznańskiego z lat 1945-1950, w których znajdują się zarówno dane ilościowe dotyczące tego zagadnienia, jak i sprawozdania opisowe lekarzy. Drugą grupę materiałów opisowych i statystycznych stanowią akta Wydziału Zdrowia Prezydium Wojewódzkiej Rady Narodowej w Poznaniu z lat 1950-1956. Obok dokumentacji zgromadzonej przez administrację szczebla wojewódzkiego w opracowaniu części opisowej artykułu posłużono się także materiałami zgromadzonymi w zespole Prezydium Miejskiej Rady Narodowej w Poznaniu z lat 1950-1956 - sprawozdania składane na se-

${ }^{3}$ Od 1950 r. raporty były przekazywane do Wydziału Zdrowia Prezydium Wojewódzkiej Rady Narodowej. 
sjach plenarnych Miejskiej Rady Narodowej przez urzędników. Wykorzystano także informacje zawarte w zespole Państwowego Urzędu Repatriacyjnego Wydziale Wojewódzkim w Poznaniu z lat 1945-1951. Materiały zgromadzone w Archiwum Państwowym w Poznaniu były zatem podstawą do opracowania statystyk dotyczących chorób zakaźnych, a także posłużyły do sformułowania wniosków i próby zinterpretowania przedstawionego zjawiska.

\section{Obszar badań}

W skład województwa poznańskiego ${ }^{4}$ w latach 1945-1950 wchodziły nie tylko powiaty, które do września 1939 r. stanowiły to województwo, ale także tereny z przyłączonej w czerwcu 1945 r. części Okręgu III - Pomorze Zachodnie Ziem Odzyskanych z Piłą, Gorzowem i Zieloną Górą jako głównymi ośrodkami administracyjnymi. Pod względem terytorialnym było to $\mathrm{w}$ latach 1946-1950 największe województwo w Polsce. Liczyło 41 powiatów, z czego dwa miały status powiatów grodzkich, czyli miast na prawach powiatu: Poznań i Gniezno ${ }^{5}$.

Reforma administracyjna z roku $1950^{6}$ pomniejszyła obszar województwa poznańskiego o powiaty, które utworzyły województwo zielonogórskie (babimojski, gorzowski, gubiński, krośnieński, międzyrzecki, rzepiński, skwierzyński, strzelecki, świebodziński, wschowski i zielonogórski). Oprócz nich odcięto z obszaru województwa poznańskiego powiat żniński i mogileński na rzecz województwa bydgoskiego. Dodatkowo w ramach województwa poznańskiego utworzono nowe powiaty grodzkie w miastach: Kalisz, Leszno, Piła i Ostrów Wielkopolski. W ramach zmian strukturalnych przedwojennego obszaru województwa poznańskiego wyodrębniono również w latach 1954 oraz 1956 trzy nowe powiaty: ostrzeszowski, pleszewski i słupecki. Podsumowując, w latach 1950-1953 województwo poznańskie tworzyło ostatecznie 32 powiaty, z czego sześć było powiatami grodzkimi - miastami na prawach powiatu.

W odniesieniu do roku 1946 uzyskano dane dla 23 powiatów. Celowo pominięto powiaty grodzkie, które funkcjonowały w innych warunkach pod względem dostępności do szpitali, kwalifikacji personelu medycznego, gęstości zaludnienia i możliwości podjęcia administracyjnych działań inter-

\footnotetext{
${ }^{4}$ Rozporządzenie Rady Ministrów z dnia 29 maja 1946 r. w sprawie tymczasowego podziału administracyjnego Ziem Odzyskanych, Dz.U. 1946, nr 28, poz. 177.

${ }^{5}$ H. Szczegóła, Przeobrażenia ustrojowo-społeczne na Ziemi Lubuskiej w latach 1945-1947, Poznań 1971, s. 44.

${ }^{6}$ Ustawa z dnia 28 czerwca 1950 r. o zmianach podziału administracyjnego Państwa, Dz.U. 1950, nr 28, poz. 255.
} 
wencyjnych. Większość danych, którymi dysponuje Archiwum Państwowe w Poznaniu, dotyczy powiatów, znajdujących się w obszarze województwa poznańskiego po reformach administracyjnych z $1950 \mathrm{r}$. Sprawozdania epidemiologiczne lekarzy powiatowych powiatu międzyrzeckiego oraz słubickiego z roku 1946 to jedyne materiały z danymi dotyczącymi Ziem Odzyskanych, które znalazły się w zespole Wydziału Zdrowia Urzędu Wojewódzkiego Poznańskiego z lat 1945-1950, znajdującym się w Archiwum Państwowym w Poznaniu. Dostępne były także dane dla powiatu żnińskiego, należącego po 1950 r. do województwa bydgoskiego. Brak większości danych dla powiatów leżących w obszarze tzw. Ziem Odzyskanych można tłumaczyć faktem tworzenia się polskiej administracji bądź po prostu brakiem lekarza powiatowego w pierwszych miesiącach po wojnie. Może to wynikać również z tego, że sprawozdania z powiatów leżących na terenie ziemi lubuskiej mogły znaleźć się w zespole Delegatura Urzędu Wojewódzkiego Poznańskiego w Gorzowie, znajdującym się w Archiwum Państwowym w tym mieście. Dane dla kolejnych lat były już pełniejsze, jednak przesunięcie okresu badawczego o kolejny rok nie pozwoliłoby na ściślejsze powiązanie zachorowań na choroby zakaźne ze skutkami działań wojennych.

Dane uzyskane na podstawie analizy materiałów Archiwum Państwowego w Poznaniu dla roku 1953 obejmują 26 powiatów i sześć miast na prawach powiatów. Można zatem powiedzieć, że jest to pełna informacja dotycząca sytuacji epidemiologicznej w województwie poznańskim tego okresu i dostępne dane obejmują wszystkich jego mieszkańców. Ze względu na porównywalność informacji $\mathrm{w}$ artykule zamieszczono jedynie dane dla powiatów ziemskich.

\section{Materiały archiwalne}

Głównym źródłem danych liczbowych były akta Wydziału Zdrowia Urzędu Wojewódzkiego Poznańskiego z lat 1945-1950 oraz akta Wydziału Zdrowia Prezydium Wojewódzkiej Rady Narodowej w Poznaniu z lat 1950-1956. Oba zespoły są dostępne w Archiwum Państwowym w Poznaniu. Znajdują się $\mathrm{w}$ nich się zarówno ważne dla omawianego zagadnienia cotygodniowe lub comiesięczne raporty lekarzy powiatowych z tabelarycznymi zestawieniami zachorowalności na choroby zakaźne, jak i dołączane do nich sprawozdania opisowe przebiegu zakażenia. W tych ostatnich często znajdują się interesujące informacje dotyczące wybuchu epidemii, obszaru jej występowania oraz tempa jej przebiegu.

Wykazy chorób zakaźnych, przesyłane co tydzień przez lekarza powiatowego do Wydziału Zdrowia w Poznaniu, stały się głównym źródłem da- 
nych ilościowych. Statystyki chorób zakaźnych są dostępne zarówno dla roku 1946, jak i dla roku 1953, w którym składano takie raporty już z terenów województwa poznańskiego w granicach z lat 1950-1975. Niestety, nie zachowały się $\mathrm{w}$ dokumentach zestawienia z pozostałych lat tego okresu.

Przesyłane cotygodniowe, a potem comiesięczne raporty o chorobach zakaźnych występujących $\mathrm{w}$ danym powiecie zwykle miały postać gotowych formularzy (Ryc. 1.), zawierających takie informacje, jak gmina i wieś, w której wykryto przypadek zachorowania. Natomiast w rubrykach oznaczonych nazwami poszczególnych jednostek chorobowych wpisywano liczbę zachorowań i zgonów, jakie wystąpiły w danym okresie sprawozdawczym. Na formularzu znajdowała się również pieczęć i podpis lekarza zatwierdzającego sprawozdanie.

W tym samym zespole można było trafić zarówno na sprawozdania na gotowych formularzach, jak i sporządzone ręcznie (Ryc. 2.). Te ostatnie przypadki dotyczyły szczególnie pierwszych lat po wojnie. Zwykle takie sprawozdania zawierały więcej informacji. Znajdowały się tam często nazwiska osób chorujących i ich stopień pokrewieństwa oraz dzienne daty zachorowań. Dzięki temu, można odtworzyć tempo i zakres rozprzestrzeniania się choroby. Brak gotowego formularza był z pewnością utrudnieniem dla personelu medycznego badanego okresu. Niemniej jednak dzięki tej sytuacji możliwe było zamieszczenie zwykle bardziej szczegółowych opisów przebiegu choroby czy epidemii. Przykłady takich raportów przedstawiono na Ryc. 2.-5.

W pracy dane ilościowe skonfrontowano z opisami historycznymi, dotyczącymi tego okresu. Wybrane problemy związane z ruchami ludności opisano w oparciu o materiały archiwalne zgromadzone w zespole Prezydium Miejskiej Rady Narodowej w Poznaniu z lat 1950-1956 - sprawozdania składane na sesjach plenarnych Miejskiej Rady Narodowej przez urzędników, oraz w zespole zatytułowanym Państwowy Urząd Repatriacyjny - Wydział Wojewódzki w Poznaniu z lat 1945-1951. Dzięki temu możliwe było uzyskanie pełniejszego obrazu sytuacji epidemiologicznej w Wielkopolsce zaraz po zakończeniu działań wojennych i po kilku latach funkcjonowania w nowej rzeczywistości społeczno-gospodarczej.

\section{Choroby zakaźnie występujące w Polsce w latach czterdzie- stych i pięćdziesiątych XX w.}

Szczegółową analizę danych archiwalnych należy rozpocząć od krótkiej charakterystyki chorób zakaźnych wspominanych w dokumentach archiwalnych. Na formularzach Wykaz zachorowań na choroby zakaźne w powie- 


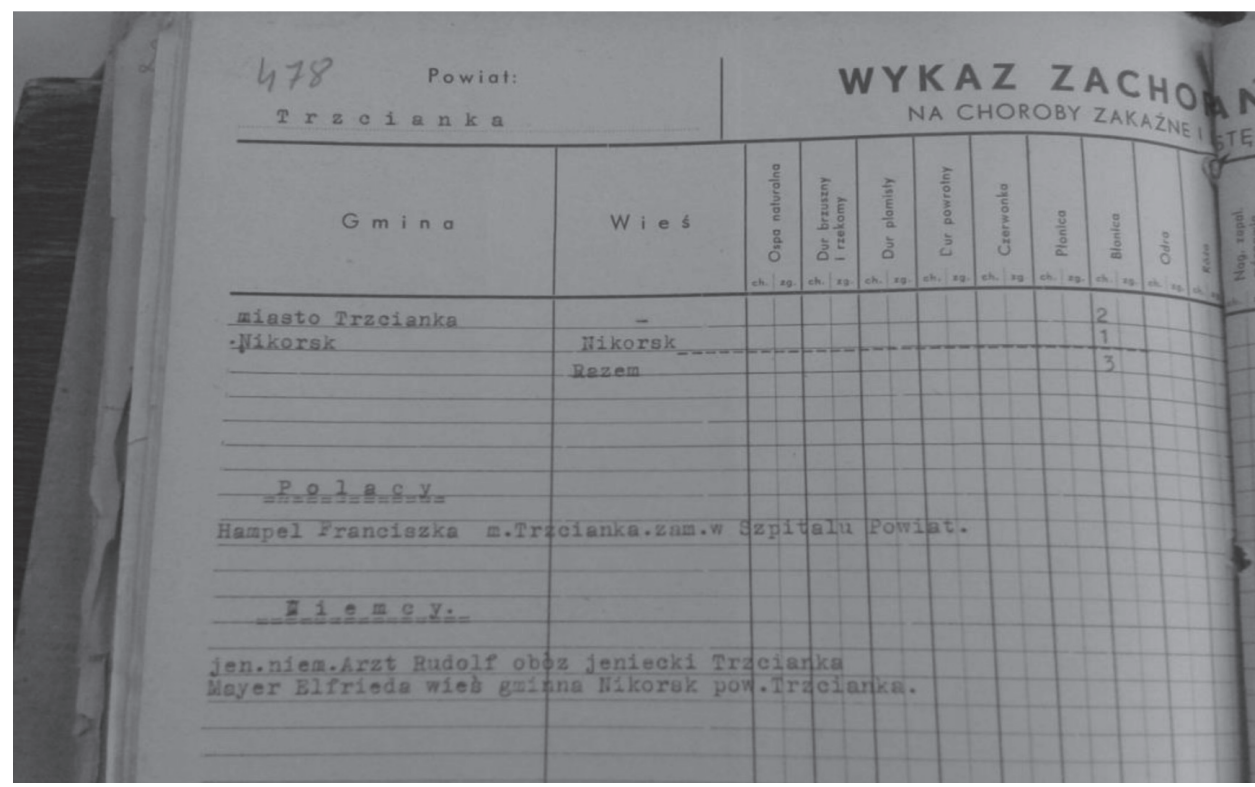

Ryc. 1. Strona formularza „Wykaz zachorowań na choroby zakaźne w powiecie” przygotowanego dla powiatu trzcianeckiego $\mathrm{w}$ roku 1946

Źródło: APP, Urząd Wojewódzki Poznański w Poznaniu, sygn. 3241, k. 478.

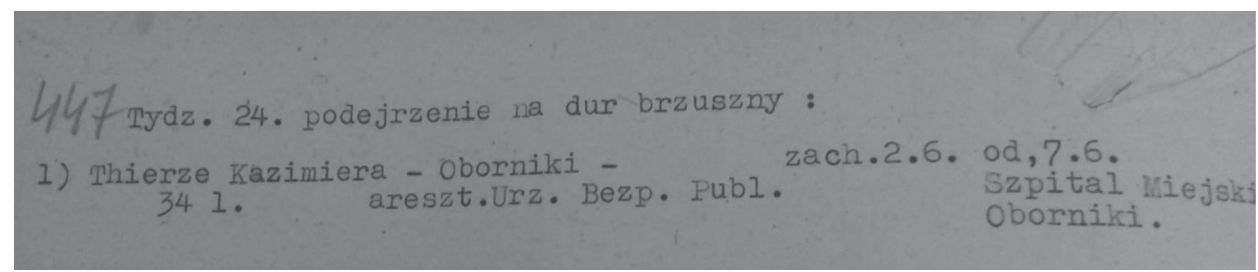

Ryc. 2. Strona z wykazu zachorowań na choroby zakaźne w powiecie obornickim z czerwca $1946 \mathrm{r}$.

Źródło: APP, Urząd Wojewódzki Poznański w Poznaniu, sygn. 3241, k. 447.

cie (por. Ryc. 1.) zostały one zapisane w zależności od roku składania raportu w kolejności: dur brzuszny, dur plamisty, płonica, błonica, odra, róża, zimnica, gruźlica, jaglica, paratyfus i choroby weneryczne. Współcześnie ich objawy, dzięki szczepionkom i poprawie warunków życia, są mało znane. Ich charakterystykę przygotowano w oparciu o informację z Matej encyklopedii zdrowia ${ }^{7}$. Opis ograniczono do wskazania podstawowych objawów każdej z chorób oraz drogi zakażenia. Ta ostatnia jest ważna ze względu na pró-

\footnotetext{
${ }^{7}$ Mała encyklopedia zdrowia, red. J. Wolański, E. Rużyłło, Warszawa 1973.
} 


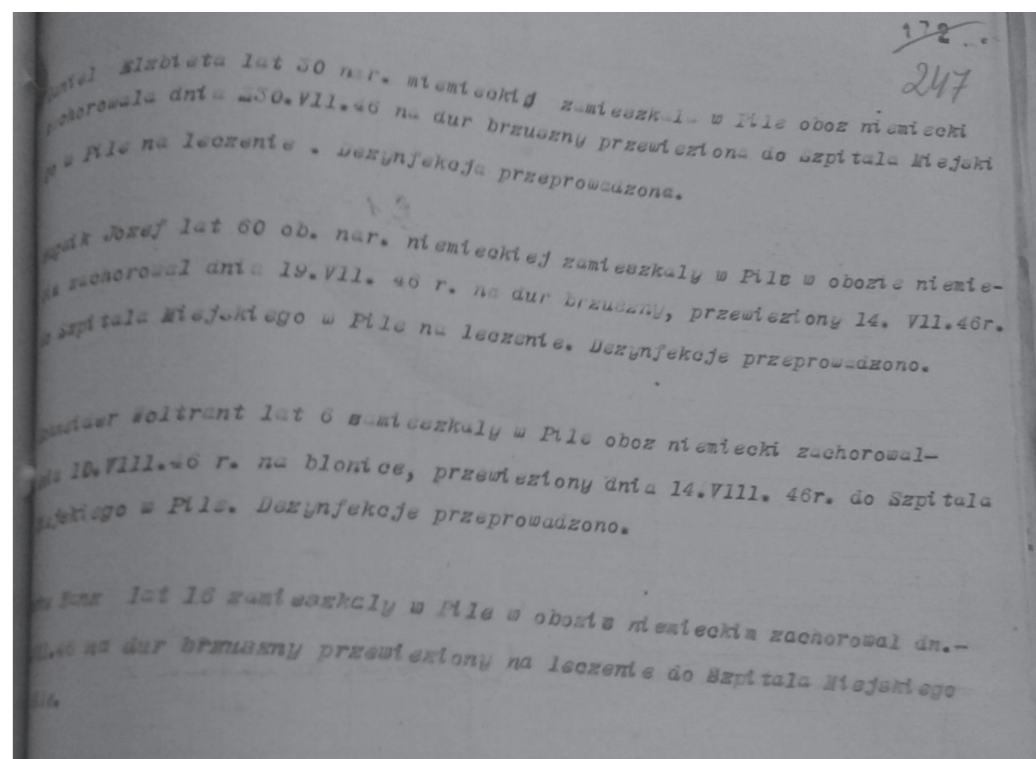

Ryc. 3. Strona z wykazu zachorowań na choroby zakaźne w powiecie pilskim z roku 1946

Źródło: APP, APP, Urząd Wojewódzki Poznański w Poznaniu, sygn. 3241, k. 247.

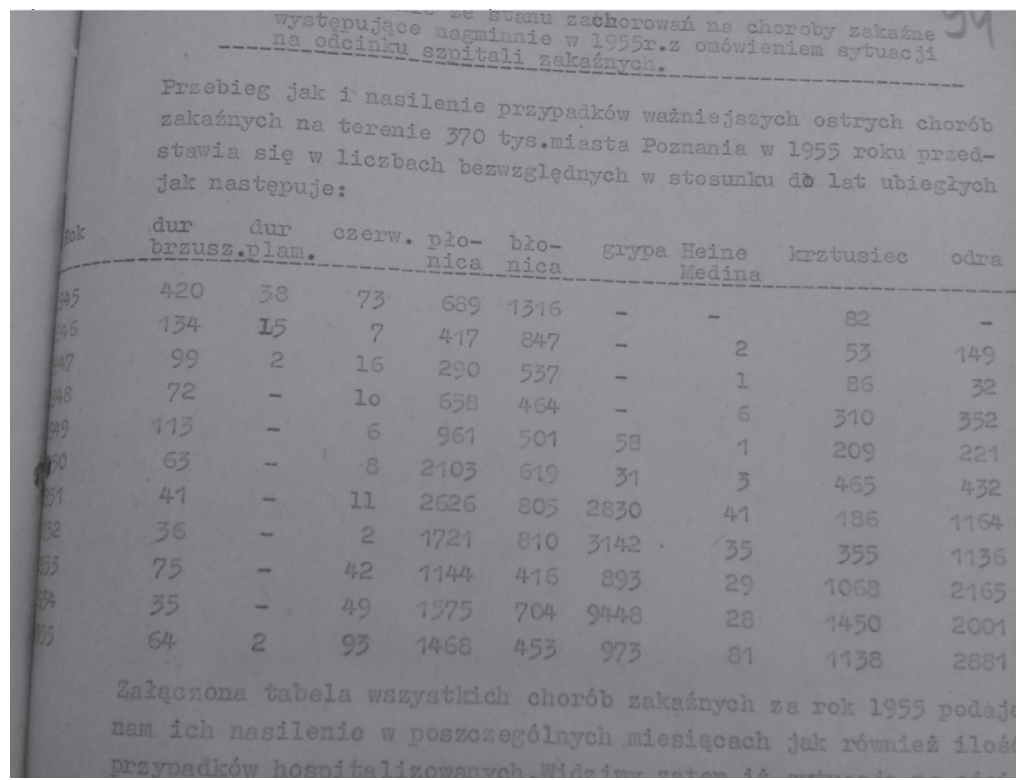

Ryc. 4. Zestawienie zachorowań na choroby zakaźne w mieście Poznaniu w roku 1955

Źródło: APP, Prezydium Miejskiej Rady Narodowej w Poznaniu, sygn. 63, k. 94. 


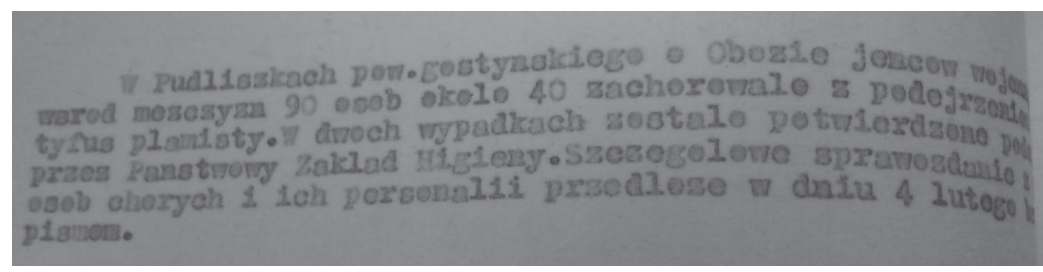

Ryc. 5. Informacja lekarza powiatowego z powiatu gostyńskiego w tygodniowym zestawieniu zachorowań na choroby zakaźne z roku 1946 Źródło: APP, Urząd Wojewódzki Poznański w Poznaniu, sygn. 3236, k. 16.

bę wskazania okoliczności, jakie mogły zaistnieć w momencie występowania wymienionych chorób.

Pierwsza z chorób zakaźnych to DUR BRZUSZNY (Typhus abdominalis). Jednostka ta, także nazywana tyfusem, jest chorobą bakteryjną, wywoływaną pałeczką Salmonelli Typhi z grupy D. Towarzyszą jej: bezsenność, bóle głowy, bóle mięśni, bóle brzucha, zaparcia, a niekiedy angina. Po ustabilizowaniu się wysokiej temperatury w początkowej fazie choroby na skórze tułowia występuje różyczka durowa, bolesność i powiększona śledziona, zapalenie oskrzeli, czasem zapalenie żył. Okres wylęgania wynosi od trzech do $56 \mathrm{dni}$ (przeciętnie 7-21 dni). Źródłem zakażenia jest chory człowiek lub nosiciel wydalający pałeczki z kałem lub moczem. Nośnikiem bakterii jest woda lub żywność, czasem brudne ręce.

Z kolei DUR WYSYPKOWY (Typhus exenthematicus), inaczej nazywany tyfusem plamistym, występuje $\mathrm{w}$ dwóch postaciach: epidemicznej i nawrotowej. Jest to ostra choroba zakaźna, bakteryjna, wywoływana przez bakterie Ricettsia prowaazeki. Bakteria ta w odmianie epidemicznej jest przenoszona przez wesz odzieżową, czasami głowową. Jej objawy to: silne bóle głowy, utrzymująca się przez ok. dwa tygodnie gorączka sięgająca $40^{\circ} \mathrm{C}$ oraz wysypka plamista, często krwotoczna. Druga odmiana tyfusu plamistego występuje u osób starszych, które w młodości przebyły dur wysypkowy epidemiczny. Ma ona łagodny przebieg, o skąpej wysypce plamisto-grudkowej.

Współcześnie rodzicom małych dzieci znana jest szkarlatyna (do łacińskiej nazwy tej choroby). W dokumentacji lekarzy powiatowych jednostka ta zapisana została jako PŁONICA (Scarlatina). Jest to choroba zakaźna, bakteryjna, wywoływana przez paciorkowiec ropotwórczy - Streptococcus pyogenes. Jej pierwsze objawy to: wymioty, wysoka gorączka, zapalenie gardła lub angina. Objawem kolejnym jest obłożenie języka - „malinowy język”. Po przebyciu płonicy mogą występować powikłania - zapalenie nerek lub gorączka reumatyczna. Okres wylęgania szkarlatyny wynosi od jednego do trzech dni. Zakażenie szerzy się drogą kropelkową.

Następna choroba zakaźna typu bakteryjnego to BŁONICA (Diphteria), znana także pod nazwą dyfteryt. Należy ona do grupy ostrych chorób za- 
kaźnych. Wywołuje ją maczugowiec błonicy (Corynebacterium diphterise). Charakteryzuje się występowaniem zmian pod postacią błoniastych nalotów. Choroba może przebiegać bardzo ciężko z porażeniami nerwów obwodowych i uszkodzeniem mięśnia sercowego. Najczęstsze jej postacie to - błonica gardła i krtani, nosa, rzadziej skóry i oka. Okres wylęgania tej choroby wynosi od dwóch do pięciu dni. Zakażenie dyfterytem szerzy się drogą kropelkową.

Kolejna wymieniana w zestawieniach choroba zakaźna, tym razem o charakterze wirusowym, to ODRA (Morbilli). Wywoływana jest ona przez wirus z grupy paramyksowirusów. Jej główne objawy to: grudkowo-plamista wysypka za uszami, na twarzy i na tułowiu, gorączka, kaszel, katar i zapalenie spojówek. Okres wylęgania odry wynosi od dziewięciu do czternastu dni. Przenosi się ona drogą kropelkową.

Z kolei RÓŻA (Erysipelas) to zakaźna choroba bakteryjna wywoływana przez paciorkowca ropotwórczego (Streptococcus pyogenes). Przebiega z gorączką, ostrym zapaleniem skóry w miejscu wtargnięcia zarazka - najczęściej twarzy lub kończyn dolnych. Okres wylęgania wynosi dla tej choroby od jednego do czterech dni. Źródłem zakażenia jest człowiek zarażony paciorkowcem, gdyż zarazek wnika przez uszkodzoną skórę.

Następna choroba zakaźna występująca w zestawieniach z 1946 r. to ZIMNICA (malaria, plasmodium). Jest to choroba pasożytnicza. Przebiega z napadami gorączki sięgającymi $40-42^{\circ} \mathrm{C}$, której towarzyszą: dreszcze, bóle głowy, nudności, zlewne poty, niedokrwienność. Pierwszy okres napadów trwa od jednego do ośmiu tygodni. Nawroty choroby mogą występować przez dwa-trzy lata. Źródłem zarażenia jest człowiek, a do zarażenia dochodzi za pośrednictwem komara widliszka.

Jedną z najbardziej znanych chorób zakaźnych i jednocześnie najbardziej śmiertelnych jest GRUŹLICA (tuberculosis). Wywołująją bakterie, zwane prątkami gruźlicy lub prątkami Kocha (Mycobacterium tuberculosis). Najczęściej występującą postacią jest gruźlica płucna. Jednak choroba ta może również atakować: ośrodkowy układ nerwowy, układ limfatyczny, naczynia krwionośne, układ kostno-stawowy, moczowo-płciowy oraz skórę. Głównym objawem gruźlicy płucnej jest kaszel, początkowo suchy, później mokry. Pojawiają się także objawy towarzyszące w postaci osłabienia, zmęczenia, senności, lekko podwyższonej temperatury ciała, spadku wagi czy bólów w klatce piersiowej. Gruźlica przenosi się głównie drogą kropelkową. Choroba może rozprzestrzeniać się także drogą pokarmową i przez dotyk. W środowiskach o wysokim standardzie życia pojawia się dużo rzadziej, zwykle jako choroba przewieziona podczas podróży z rejonów endemicznych.

W oficjalnym zestawieniu dla Wydziału Zdrowia Urzędu Wojewódzkiego występują również: PARATYFUS, czyli dur rzekomy, czerwonka oraz choroby weneryczne. Objawy pierwszej z chorób są bardzo zbliżone do duru brzusznego, ale o znacznie lżejszym przebiegu. W związku z tym bez badań 
laboratoryjnych trudno było rozdzielić te dwie jednostki chorobowe. Z kolei chorób wenerycznych zwykle nie wykazywano w zestawieniach, w związku z tym, że walką z nimi zajmowały się odrębne zespoły utworzone do tego celu. Źródłem zakażenia czerwonką jest natomiast nieprzegotowana woda, a nie drugi człowiek. Dlatego także tej ostatniej nie uwzględniono w analizie.

\section{Wyniki badań archiwalnych}

W sprawozdaniu Wydziału Zdrowia Urzędu Wojewódzkiego Poznańskiego z września 1945 r. zaznaczono, że w całym województwie poznańskim wiosną tego roku zaobserwowano dwa duże ogniska duru plamistego - tyfusu. Jedno z nich znajdowało się pod Pleszewem w majątku Malinie należącym do tego miasta (w $1945 \mathrm{r}$. leżący w powiecie jarocińskim). Z transportu repatriantów przybyłych tu z powiatu zborowskiego w województwie tarnopolskim zachorowało na tyfus 319 osób, z czego zmarło 26 chorych $^{8}$. Drugim ogniskiem tyfusu była Chodzież na północy województwa poznańskiego. Tu w maju 1945 r. wśród repatriantów w istniejącym na terenie miasta punkcie etapowym zanotowano 139 zachorowań na tyfus. Spośród grupy zakażonych zmarło dwanaście osób ${ }^{9}$. Przygotowanie do walki z epidemią tyfusu było w Chodzieży zdecydowanie lepsze niż w Pleszewie (powiat jarociński) każdy transport repatriantów poddawano tu kwarantannie. Dla tych działań, w porozumieniu pomiędzy PUR, Miejską Radą Narodową i Starostwem Powiatowym w Chodzieży, zajęto miejscowe sanatorium chorób płucnych ${ }^{10}$.

Nieco mniej groźną chorobą, przenoszoną podobnie jak dur plamisty, był dur brzuszny. W sprawozdaniu Wydziału Zdrowia Urzędu Wojewódzkiego Poznańskiego do września 1945 r. zanotowano ponad 2100 zachorowań na tę chorobę. Zmarło w jej wyniku 125 osób zakażonych. Główne ogniska choroby zlokalizowano $\mathrm{w}$ powiecie poznańskim $-\mathrm{w}$ tym m.in. $\mathrm{w}$ miejscowości Mrowino koło Cerekwicy (powiat żniński), w której znajdował się obóz pracy - oddział półotwarty więzienia w Poznaniu. Kolejne ogniska choroby to powiat szamotulski - $\mathrm{w}$ tym miasto Wronki - tu $\mathrm{z}$ kolei znajdował się jeden

8 APP, Urząd Wojewódzki Poznański w Poznaniu, sygn. 3250, „Sprawy zwalczania duru plamistego", k. 34-36, oraz wspomnienia repatrianta zawarte w artykule Kazimierza Dajczaka Trościeniec Wielki - nasi wybitni rodacy - ks. Stanisław Kusiak, www.http:/ / kdajczak.republika.pl/ s_kusiak.html (dostęp 12 września 2013 r.).

9 APP, Urząd Wojewódzki Poznański w Poznaniu, sygn. 3250, „Sprawy zwalczania duru plamistego", k. 34-36.

10 Tamże, k. 1, Informacja z dnia 7 maja 1945 r. Starostwa Powiatowego w Chodzieży dla Urzędu Wojewódzkiego Poznańskiego o epidemii tyfusu. 
z największych zakładów karnych. W powiatach: mogileńskim, kaliskim i tureckim, zlokalizowano pojedyncze ogniska duru brzusznego ${ }^{11}$.

Przeprowadzona kwerenda archiwalna pozwoliła na zebranie tygodniowych i miesięcznych danych o występowaniu chorób zakaźnych w poszczególnych powiatach dla dwóch lat okresu powojennego. Po ich odpowiednim zsumowaniu otrzymano zestawienia roczne dotyczące zachorowań, które zostały przedstawione $\mathrm{w}$ tab. 1 . i w tab. 2., odpowiednio $\mathrm{w}$ odniesieniu do roku 1946 oraz 1953. Jak wspomniano wcześniej, dodatkowo spośród danych dotyczących drugiego badanego okresu pominięto te dotyczące powiatów grodzkich. Obie tabele przesortowane zostały wg liczby zachorowań i częstości występowania poszczególnych chorób zakaźnych. W sposób analogiczny przygotowano zestawienia dotyczące śmiertelności na choroby zakaźne. W dwóch kolejnych tabelach (tab. 3. i tab. 4.) przedstawiono dane dotyczące roku 1946 i 1953. Uwzględniono w nich tylko te choroby zakaźne, dla których odnotowano przypadki śmiertelne. Dodatkowo zamieszczono w nich także informacje o poziomie śmiertelności wyrażonym $\mathrm{w}$ wartościach względnych, czyli procent przypadków zachorowań, który okazał się śmiertelny.

Zaraz po wojnie wśród chorób zakaźnych najwięcej zachorowań odnotowano dla błonicy. Chorzy na tę chorobę stanowili 42 proc. przypadków zgłoszonych zachorowań na choroby zakaźne w województwie poznańskim w 1946 r. Powiaty, w których odnotowano najwięcej zachorowań na tę chorobę (więcej niż dwieście), to: wolsztyński, wągrowiecki, nowotomyski, poznański, koniński, gostyński, kościański i czarnkowski. Na kolejnych miejscach pod względem zachorowalności znalazły się gruźlica i dur brzuszny. Przypadki zachorowań na te choroby stanowiły odpowiednio szesnaście i czternaście proc. wszystkich zgłoszonych zachorowań na choroby zakaźnie w roku 1946 w województwie poznańskim. Przypadków gruźlicy było najwięcej w powiatach: poznańskim, konińskim, gnieźnieńskim oraz wrzesińskim, a zatem w miejscach najbardziej zaludnionych. Z kolei główne źródła duru brzusznego mieściły się $\mathrm{w}$ powiatach nowotomyskim oraz konińskim.

W okolicach dziesięciu proc. wszystkich zgłoszonych zachorowań na choroby zakaźnie oscylowały płonica i jaglica. Płonica wyraźnie zadomowiła się w powiatach poznańskim i chodzieskim, a ognisko jaglicy zlokalizowane było na wschodzie Wielkopolski: w powiatach konińskim oraz kolskim. Zachorowalność na odrę, zimnicę, dur plamisty i różę stanowiło mniej niż pięć proc. zgłoszonych zachorowań.

Biorąc z kolei pod uwagę powiaty, które w największym stopniu zmagały się z chorobami zakaźnymi, trzeba ponownie wymienić powiaty: koniński, poznański, nowotomyski, wągrowiecki i wolsztyński. Najmniej zachorowań odnotowano natomiast w powiatach: pilskim, słubickim i żnińskim. Można

11 Tamże, k. 34-36. 
zatem powiedzieć, że gęstość zaludnienia i bliskość dużych ośrodków miejskich miała silny wpływ na zachorowalność na choroby zakaźne.

Analiza danych dotyczących liczby zachorowań na choroby zakaźnie w województwie poznańskim w 1953 r., przedstawionych w tab. 2., pozwala od razu zauważyć, że struktura zachorowań była zupełnie inna. Czwarta część zgłoszonych przypadków zachorowań (ok. 25 proc.) na choroby zakaźnie dotyczyła odry. Jej główne ogniska znajdowały się w powiatach: kościańskim, konińskim, szamotulskim, nowotomyskim, jarocińskim, wągrowieckim, kolskim oraz krotoszyńskim.

Drugą co do liczby zachorowań chorobą zakaźną był krztusiec, który stanowił osiemnaście proc. zgłaszanych przypadków zachorowań na choroby zakaźne. Struktura geograficzna zachorowań jest tu zbliżona do tych na odrę, choć bardziej skupiona. Oprócz wymienionych powyżej powiatów trzeba w tym przypadku dodać powiaty: ostrowski, gostyński oraz gnieźnieński.

Płonica i grypa stanowiły w 1953 r. po ok. trzynaście proc. wszystkich zachorowań na choroby zakaźne. W przypadku grypy można mówić o wyraźnym jej ognisku w powiatach: nowotomyskim, jarocińskim oraz z nimi sąsiadujących. Płonica swe żniwo zebrała głównie w powiatach: kościańskim, poznańskim oraz śremskim.

Pewne znaczenie wśród zachorowań na choroby zakaźne odegrały także gruźlica i błonica, stanowiące odpowiednio dziewięć i siedem proc. zachorowań. Gruźlica to choroba występująca przede wszystkim w powiatach wschodniej i południowej Wielkopolski: konińskim, kaliskim i kolskim. Z kolei najwięcej przypadków błonicy odnotowano w powiatach - nowotomyskim i konińskim.

Zachorowalność na przyusznicę, jaglicę i dur brzuszny stanowiła pięć proc. lub mniej zachorowań. W przypadku przyusznicy o ogniskach choroby można mówić na terenie powiatów krotoszyńskiego i wągrowieckiego. Największą zapadalność na jaglicę odnotowano natomiast w powiecie kolskim i w powiecie konińskim. Zestawienie w tab. 2. pozwala także stwierdzić, że zachorowalność na dur brzuszny i różę nie przekroczyła trzech proc.

Z tego zestawienia wynika także, że w 1953 r. najbardziej narażona na pojawienie się choroby zakaźnej była ludność powiatów: kościańskiego, konińskiego, nowotomyskiego, jarocińskiego, szamotulskiego i kolskiego. Z kolei stosunkowo bezpiecznie mogli się czuć mieszkańcy powiatów: rawickiego, średzkiego, czarnkowskiego i pilskiego.

$\mathrm{W}$ tab. 3. i 4. przeanalizowano śmiertelność związaną z chorobami zakaźnymi, tak w 1946, jak i 1953 r. Największą śmiertelnością, nie tylko w ujęciu ilościowym (433 zgony), ale i względnym, charakteryzowała się gruźlica: 55 proc. wszystkich zgłoszonych zgonów związanych było właśnie z tą chorobą. Przeciętnie, niemal co trzecia osoba zapadająca na tę chorobę umierała. Najwyższy poziom śmiertelności, ponad pięćdziesiąt proc., odnoto- 


\begin{tabular}{|c|c|c|c|}
\hline 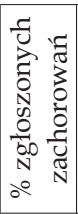 & 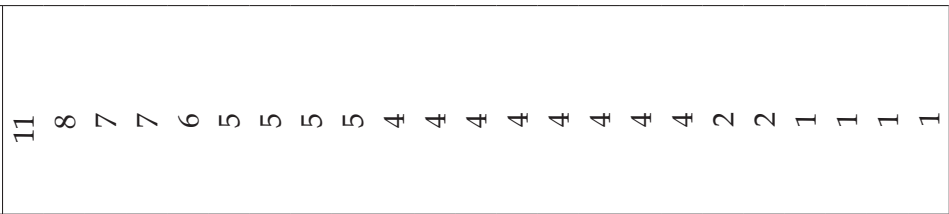 & 8 & \\
\hline $\begin{array}{l}\text { ๕్ } \\
\text { त్ } \\
\approx\end{array}$ & 유 & $\begin{array}{c}\sigma \\
\\
\infty\end{array}$ & $\stackrel{8}{\circ}$ \\
\hline : N & $\infty \pi n$ n & oे & $r$ \\
\hline 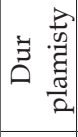 & 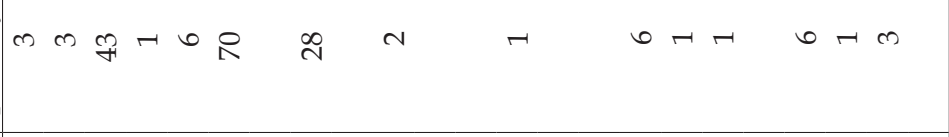 & $\stackrel{10}{\stackrel{10}{-}}$ & $N$ \\
\hline 芯 & 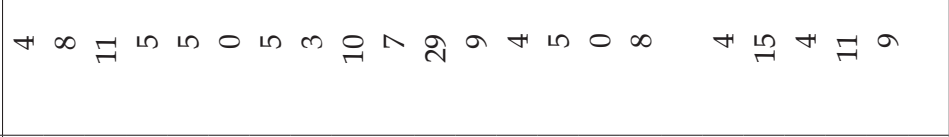 & 点 & $N$ \\
\hline$\frac{\pi}{\overparen{0}}$ & $\stackrel{n}{\sim}$ & $\begin{array}{l}\infty \\
\stackrel{\infty}{ } \\
\text { | }\end{array}$ & $\infty$ \\
\hline 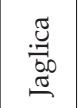 & مิ & : & $a$ \\
\hline 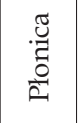 & + ํㅢ & $\begin{array}{l}\sigma \\
\sigma\end{array}$ & $F$ \\
\hline 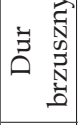 & 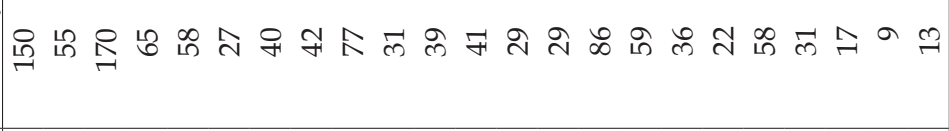 & $\underset{\infty}{\infty}$ & 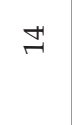 \\
\hline 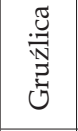 & 귝 & 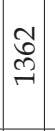 & $\stackrel{\bullet}{\sim}$ \\
\hline 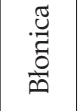 & 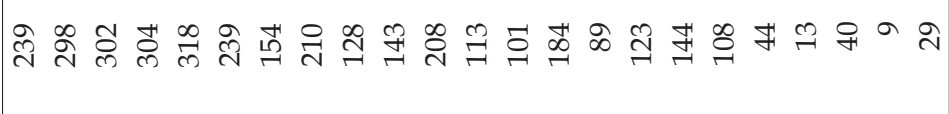 & $\begin{array}{l}9 \\
\text { th } \\
\text { m) }\end{array}$ & ㄱ \\
\hline $\begin{array}{l}. \frac{\pi}{3} \\
\sum_{0}^{2} \\
0\end{array}$ & 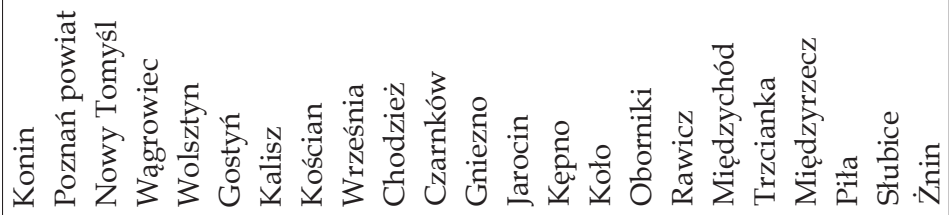 & 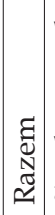 & 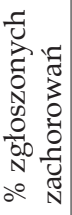 \\
\hline
\end{tabular}




\begin{tabular}{|c|c|c|c|}
\hline 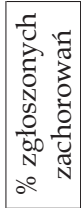 & 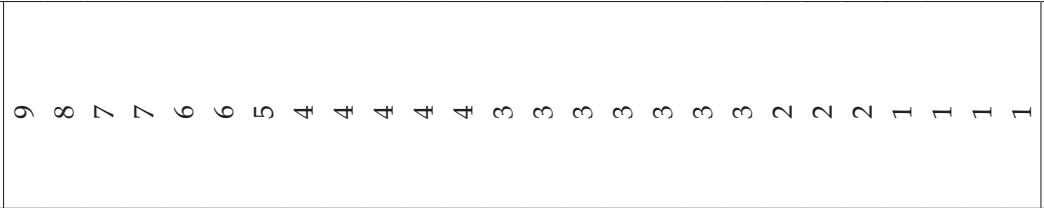 & ৪ & \\
\hline 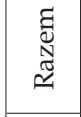 & 务 & 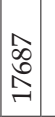 & 8 \\
\hline $\begin{array}{l}\stackrel{\pi}{N} \\
\stackrel{2}{\mathscr{V}}\end{array}$ & 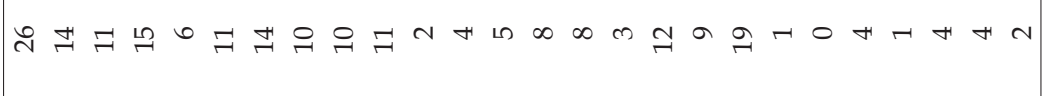 & $\vec{\sim}$ & $r$ \\
\hline 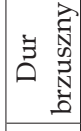 & 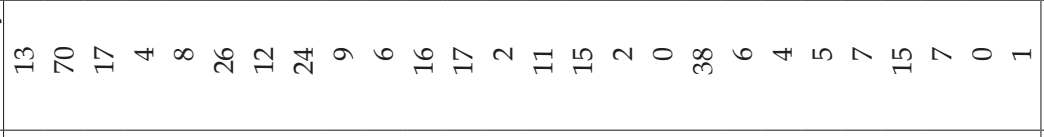 & \begin{tabular}{|c|}
$\mathrm{L}$ \\
$\mathrm{m}$ \\
$\mathrm{m}$
\end{tabular} & $\sim$ \\
\hline 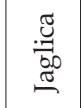 & m & જે & 10 \\
\hline 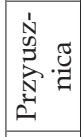 & تु & $\begin{array}{l}\infty \\
\infty \\
\infty\end{array}$ & 10 \\
\hline 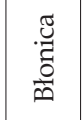 & 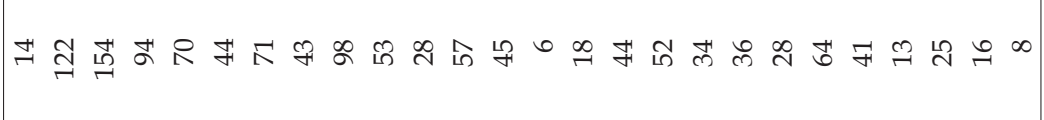 & 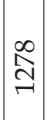 & 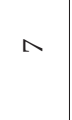 \\
\hline 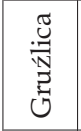 & 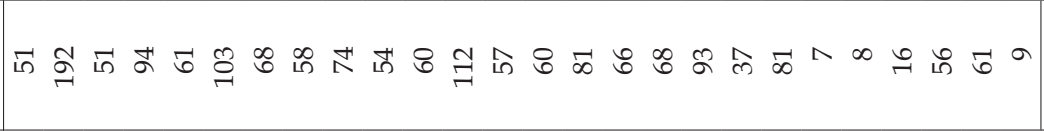 & 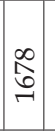 & $a$ \\
\hline 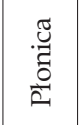 & 正 & 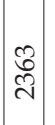 & $\stackrel{M}{\sim}$ \\
\hline$\sum_{0}^{\tilde{2}}$ & 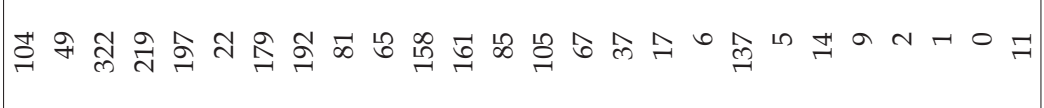 & 胥 & $\stackrel{M}{\longrightarrow}$ \\
\hline 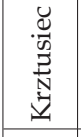 & क્રે & $\begin{array}{l}\text { స్ } \\
\text { లె }\end{array}$ & $\stackrel{\infty}{\sim}$ \\
\hline$\overparen{\pi}$ & 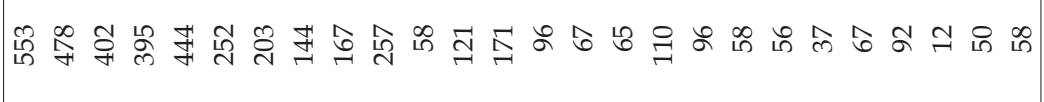 & 高 & $\stackrel{\stackrel{2}{N}}{ }$ \\
\hline & 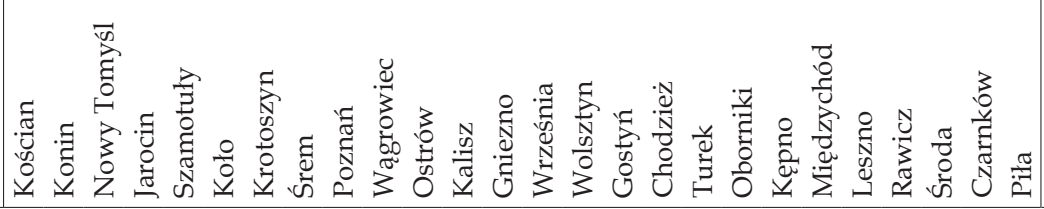 & 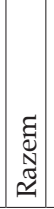 & 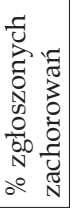 \\
\hline
\end{tabular}




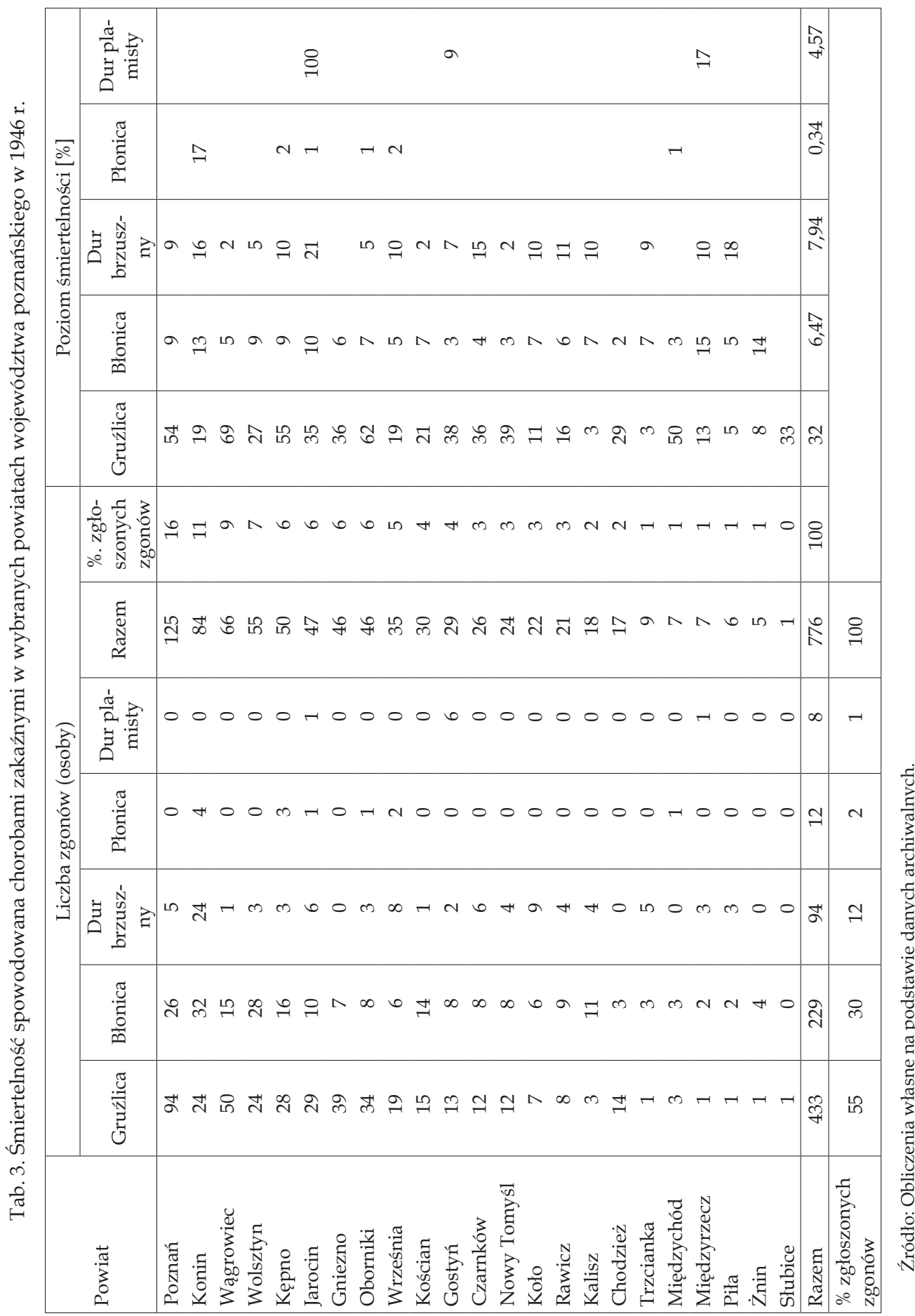




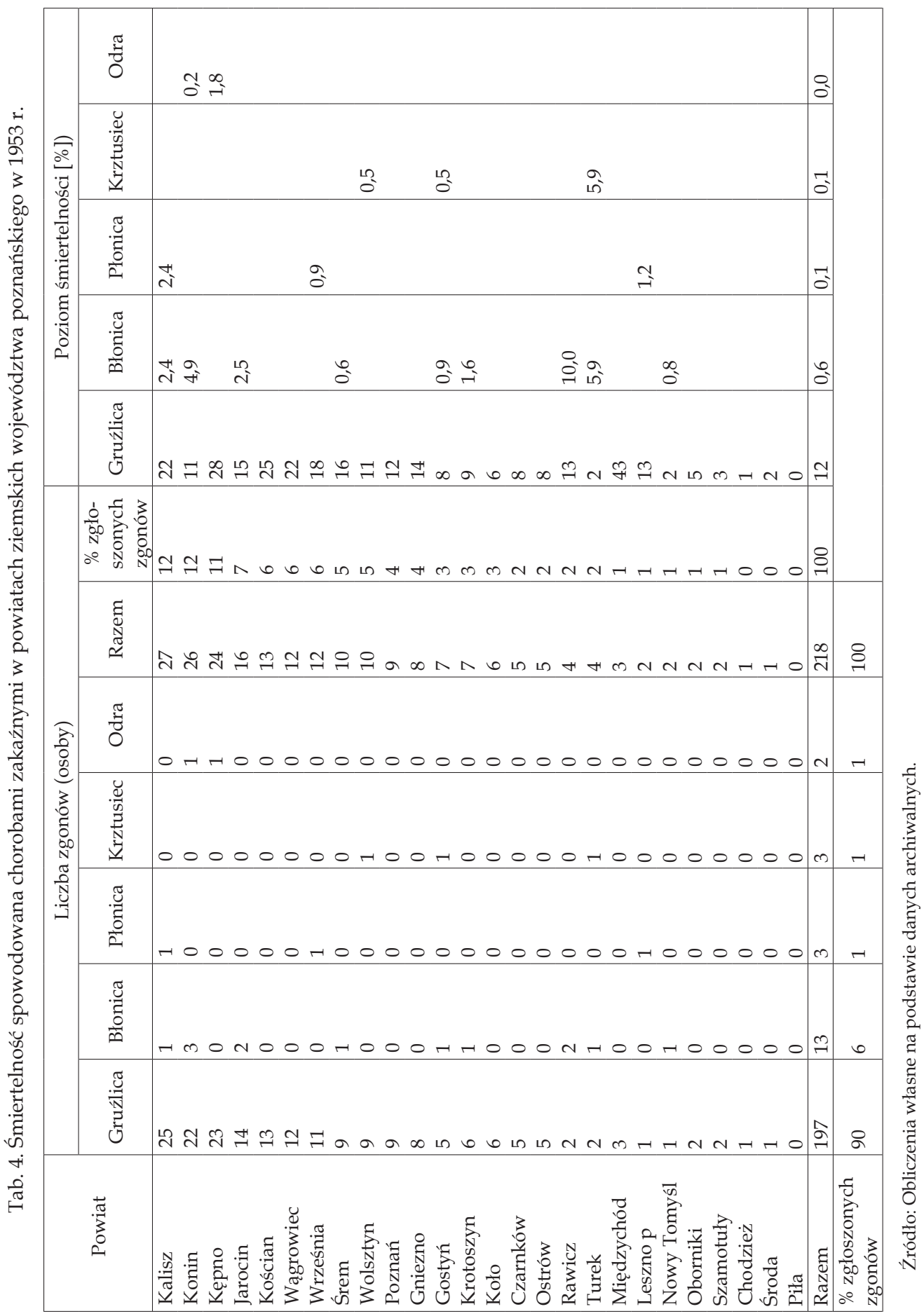


wano w powiatach: wągrowieckim, obornickim, poznańskim i międzychodzkim.

Znaczenie gruźlicy $\mathrm{w}$ analizie zgonów związanych $\mathrm{z}$ chorobami zakaźnymi wzrosło w 1953 r. Aż dziewięćdziesiąt proc. wszystkich zgonów było powiązane $\mathrm{z}$ tą chorobą. Jednak $\mathrm{w}$ ujęciu ilościowym $\mathrm{w}$ ciągu całego roku zmarło na nią jedynie 197 osób, czyli o ponad połowę mniej osób. Co więcej, poziom śmiertelności wśród chorych na gruźlicę spadł z 32 do 12 proc., czyli tylko co ósma osoba chorująca na gruźlicę umierała. Biorąc pod uwagę wieloletni przebieg tej choroby, fakt ten wydaje się dużym osiągnięciem.

Duża śmiertelność wykazywana była w 1946 r. również wśród osób chorujących na błonicę (trzydzieści proc. łącznej liczby zgłaszanych zgonów), tyfus (trzynaście proc.) i płonicę (jeden proc.). Śmiertelność związana z tyfusem, czyli durem brzusznym i plamistym, roznoszonym głównie poprzez wszy, praktycznie zniknęła w 1953 r. Z kolei śmiertelność błonicy, znanej również pod nazwą dyfteryt, ograniczona została z trzydziestu proc. wszystkich zgłoszonych zgonów w 1946 r. do sześciu proc. w roku 1953. W tym ostatnim przypadku zmarło $\mathrm{w}$ całym województwie (w powiatach ziemskich) tylko trzynaście osób zmagających się z tą chorobą.

Należy zwrócić uwagę na to, że poziom śmiertelności pozostałych chorób zakaźnych w 1953 r. ograniczono do mniej niż jednego proc. chorujących. Wyjątkiem okazała się tylko gruźlica, której śmiertelność, tak jak wspomniano wyżej, również znacząco ograniczono.

Największą liczbę przy padków śmiertelnych w 1946 r. odnotowano w powiatach: poznańskim, konińskim, wągrowieckim, wolsztyńskim i kępińskim. Liczba osób zmarłych z powodu chorób zakaźnych była w nich równa lub większa od 50. W 1953 r. wśród powiatów, które odnotowały najwyższą liczbę zgonów spowodowanych chorobami zakaźnymi, znalazły się powiaty: kaliski, koniński oraz kępiński. Tym razem jednak liczba zgonów w tych powiatach w ciągu całego badanego roku wynosiła od 24 do 27 osób.

\section{Warunki sprzyjające rozprzestrzenianiu się chorób}

\section{Wysiedlenia ludności niemieckiej}

Mimo przejścia frontu ludność niemiecka pozostała na ziemiach zachodnich nie była skłonna do opuszczania swoich miejsc zamieszkania. Dopiero zakończenie wojny w maju 1945 r. spowodowało, że polskie władze administracyjne, zarówno na terenach polskich sprzed II wojny, jak i na terenach włączonych do Polski, rozpoczęły - jeszcze przed konferencją Wielkiej Trójki w Poczdamie - akcję osadzania miejscowej ludności niemieckiej i osób wpisanych na listy VD w obozach przejściowych oraz wywożenia jej za linię przy- 


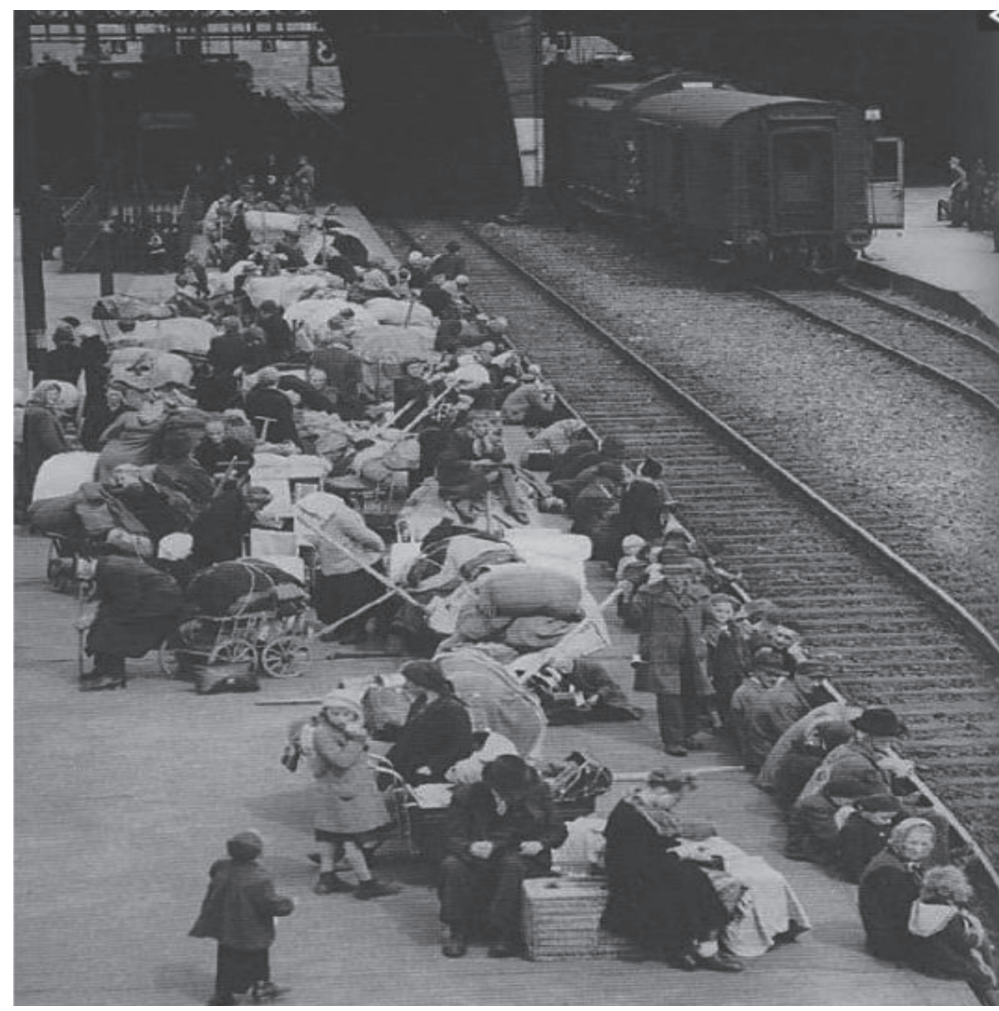

Ryc. 6. Wywóz ludności niemieckiej ze Szczecina Źródło: Archiwum Państwowe w Szczecinie, Państwowy Urząd Repatriacyjny. Szczecin 1947, sygn. 89.

szłej granicy zachodniej. Proces ten został wstrzymany przez władze centralne w czasie trwania konferencji poczdamskiej, by z początkiem 1946 r. ruszyć ponownie na wielką skalę. $Z$ tym, że wówczas administracja polska znała już miejsca, do których mieli trafiać wysiedlani z terenów Polski Niemcy - były to strefy okupacyjne rosyjska i brytyjska.

Część ludności niemieckiej - mężczyzn i kobiety zdolnych do pracy, pozostawiano w tych miejscach, gdzie na skutek braku rąk do pracy byli potrzebni jako niezbędna siła robocza. Obozy tego typu, tworzone zwykle w miejscach nieprzystosowanych do przebywania w nich większej liczby osób, traktowano jako przejściowe, mające funkcjonować co najwyżej kilka tygodni. Okazało się jednak, że ludność niemiecka przebywała tam miesiącami. Warunki sanitarne, a szczególnie brak toalet, łaźni czy podstawowego personelu medycznego, sprzyjały rozprzestrzenianiu się chorób, w tym zakaźnych.

Tego typu obozy pracy, w których przetrzymywano ludność niemiecką, funkcjonowały $w$ wielu miejscowościach województwa poznańskiego oraz w jego sąsiedztwie. Z dokumentacji Ministerstwa Bezpieczeństwa 


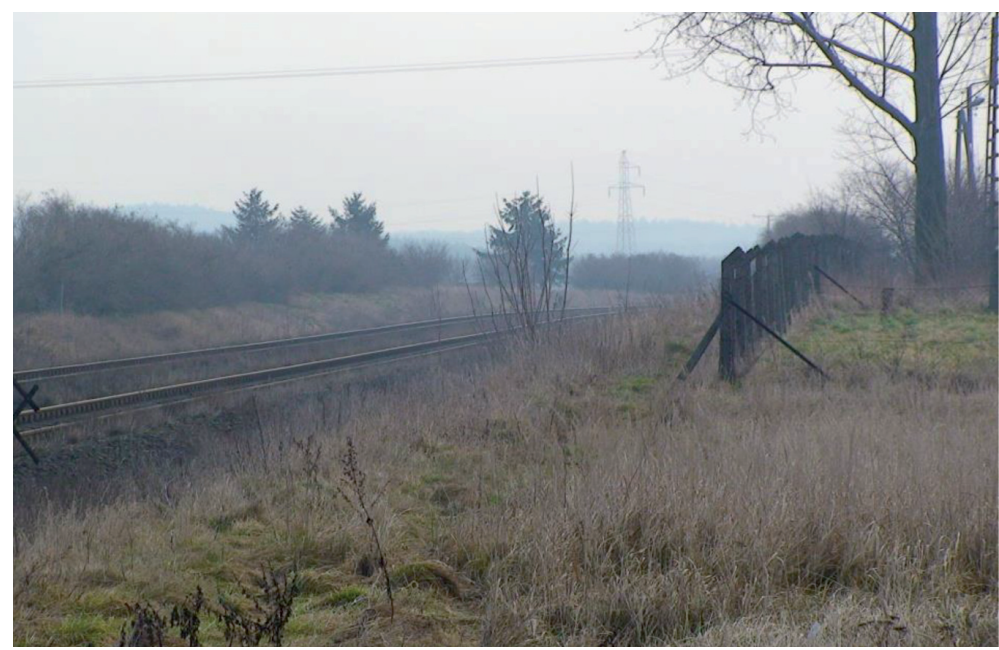

Ryc. 7. Leszno-Granowo - miejsce obozu Ministerstwa Bezpieczeństwa Publicznego dla Niemców i VD (widok z roku 2002) Źródło: Zdjęcie własne autora.

Publicznego wynika, iż w Polsce w kwietniu 1945 r. funkcjonowało szesnaście głównych obozów, z tego w województwie poznańskim - w Mrowinie (powiat poznański) i Krotoszynie (powiat krotoszyński). Pozostałe to: Mielęcin, Studzieniec, Świętochłowice-Zgoda, Jaworzno, Zimne Wody, Potulice, Jarosław, Mysłowice, Wadowice, Gdańsk, Łódź, Popkowice, Poniatowa, Łęgnowo. W sumie ulokowano w nich ponad 27 tys. więźniów, w większości Niemców i volksdeutschów. W drugiej połowie roku liczba obozów i związanych z nimi kolonii rolnych wzrosła do 28 placówek. W województwie poznańskim utworzono wówczas obóz w Lesznie-Gronowie (powiat leszczyński), a obok nich powstały również obozy w: Głazach, Kcyni, Janikowie, Kruszwicy i Inowrocławiu, Krzesimowie, Oświęcimiu, Jaksicach, Gniewkowie, Będzinie, Targowej Górce, Abramowie, Stalowej Woli, Toruniu-Rudkach, Warszawie, Złotowie $^{12}$. Przestały zaś funkcjonować obozy w: Poniatowej, Gdańsku, Krotoszynie, Wadowicach, Zimnych Wodach, Świętochłowice-Zgoda.

Z zachowanych danych wynika, iż w latach 1945-1950 w różnego rodzaju polskich obozach i w koloniach rolnych, przetrzymywano nie mniej niż 175 tys. osób oczekujących na weryfikację narodowościową. Niewiadomą stanowi liczba uwięzionych w obozach dzikich (przykładowo tylko na Śląsku Opolskim było to od dwudziestu tys. do trzydziestu tys. osób) ${ }^{13}$.

12 T. Wolsza, Obozy i inne miejsca odosobnienia na ziemiach polskich w latach 1944-1958, http:/ / klub-generalagrota.pl/kg/baza-wiedzy/referaty/624,dok.html (dostęp 12 września 2013 r.).

${ }^{13}$ Tamże. 
Niestety, wśród danych z 1946 r., na przykładzie którego zostało sporządzone zestawienie, mówiące o chorobach zakaźnych w województwie poznańskim, nie udało się znaleźć takich, które opisywałyby sytuację w powiecie leszczyńskim, którą można by powiązać z istnieniem tam obozu Leszno-Gronowo, czy w powiecie krotoszyńskim, w którym także był tego typu obóz. Niemniej jednak dane dotyczące powiatu poznańskiego w $1946 \mathrm{r}$. wskazują na dużą liczbę zachorowań na błonicę, gruźlicę oraz płonicę. Łącznie liczba zgłoszonych zachorowań na wspomniane choroby wynosiła ponad 570 osób. Liczba stwierdzonych zachorowań na gruźlicę i płonicę była najwyższa spośród zgłoszonych zestawień dla powiatów województwa.

\section{Jeńcy wojenni}

Obok obozów dla niemieckiej ludności cywilnej, już od momentu przechodzenia przez ziemie zachodnie frontu, tworzył się i funkcjonował cały system obozów jenieckich dla żołnierzy niemieckich branych do niewoli przez wojska sowieckie i oddziały 1 . Armii WP. System ten składał się z obozów przyfrontowych oraz obozów filtracyjnych. Obozy filtracyjne oddalone były od obozów przyfrontowych o ponad sto $\mathrm{km}$. Dokonywano w nich selekcji jeńców z punktu widzenia ich pozycji w armii III Rzeszy oraz roli, jaką odgrywali w systemie okupacyjnym. Do systemu należały także obozy etapowe, znajdujące się na trasie przemarszu kolumn jenieckich do ich stałych miejsc odosobnienia w ZSRR. Obozy NKWD i Głównego Zarządu Informacji Wojska Polskiego na terenie ówczesnego województwa poznańskiego zlokalizowane były m.in. w: Gorzowie Wielkopolskim, Pile, Poznaniu i Wągrowcu ${ }^{14}$.

Jednym $z$ takich obozów przejściowych i jednocześnie filtracyjnych był obóz funkcjonujący w Poznaniu przy ul. Słonecznej, znajdujący się w barakach dawnej tzw. "Gospody Targowej”, wybudowanej w 1929 r. na Powszechną Wystawę Krajową. W czasie okupacji Niemcy urządzili w niej sanatorium rehabilitacyjne dla żołnierzy Wehrmachtu. Gdy w końcu stycznia 1945 r. wojska sowieckie wkroczyły do Poznania, towarzyszące im jednostki NKWD przejęły ten obiekt i do sierpnia $1945 \mathrm{r}$. gospodarzyły w nim razem z polskim Urzędem Bezpieczeństwa. Tu obok jeńców wojennych NKWD przewiozła latem 1945 r. więźniów (żołnierzy AK) ze swojego obozu w Rembertowie. Powodem była ucieczka, jaką skutecznie przeprowadzili AK-owcy przetrzymywani w Rembertowie ${ }^{15}$. Po likwidacji tego obozu jeńcy niemieccy zostali wysłani do ZSRR, natomiast Polaków - żołnierzy AK, wysłano drogą kolejową do więzienia w Rawiczu.

\footnotetext{
14 Tamże.

15 Spectagier NKWD nr 2 w Poznaniu. Dokumenty, red. W. Handke, R. Kościański, G. Barczykowski, Poznań 2009.
} 


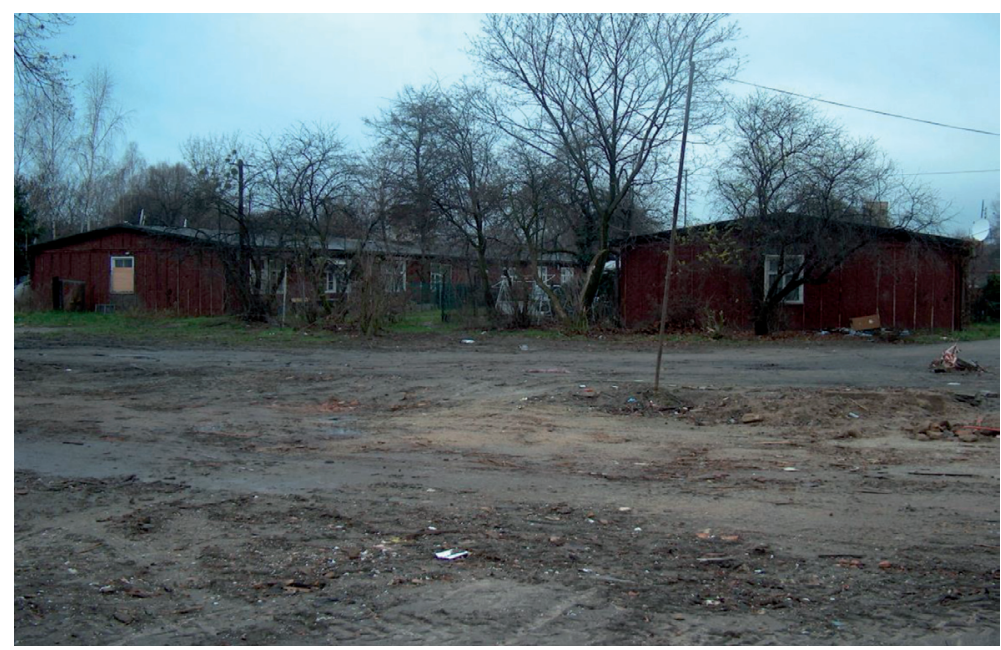

Ryc. 8. Nieistniejące już dziś pozostałości baraków byłej „Gospody Targowej” i obozu NKWD w Poznaniu przy ul. Słonecznej (widok z roku 2002) Źródło: Zdjęcie własne autora.

Innymi przykładami obozów dla jeńców niemieckich prowadzonych przez NKWD przy współpracy Informacji Wojskowej i Urzędu Bezpieczeństwa, znajdujących się na terenie województwa poznańskiego, były obozy w: Trzciance, Wągrowcu, Pile ${ }^{16}$. Obozy w Pile i Wągrowcu zostały zlikwidowane przez NKWD już w 1945 r. Na początku 1946 r. władze sowieckie rozpoczęły przekazywanie stronie polskiej tych żołnierzy Wehrmachtu, którzy pochodzili z Pomorza lub ze Śląska i przed 1939 r. byli obywatelami II Rzeczpospolitej. W obozach sprawdzano ich pochodzenie, a następnie zwalniano, tych zaś, którzy nie chcieli przyjąć obywatelstwa polskiego, wysyłano do Niemiec, do sowieckiej lub brytyjskiej strefy okupacyjnej.

Liczba jeńców wojennych uwięzionych przez polskie władze wahała się od 48 tys. jeńców (w 1945 r.) do dwudziestu tys. (w 1949 r.) ${ }^{17}$. To w tych obozach często dochodziło do wybuchu epidemii, a głównymi chorobami, jakie zbierały największe żniwo, były głównie dwie związane z brudem i brakiem higieny - dur brzuszny i dur plamisty - TYFUS. Niestety, o skali tego zjawiska niewiele wiadomo. $\mathrm{W}$ dokumentach zachowało się zaledwie kilka wzmianek i to w sytuacji, gdy jeńcy znaleźli się pod jurysdykcją polskich władz sanitarnych. Niemniej jednak w skali całego powiatu wągrowieckiego w 1946 r. wciąż występowała najwyższa zachorowalność na odrę, wysoka na dur brzuszny, gruźlicę, błonicę i płonicę, przeciętna na gruźlicę. Wskazania

\footnotetext{
${ }^{16}$ T. Wolsza, dz. cyt.

17 Tworzenie się struktur aparatu bezpieczeństwa na terenie powiatu złotowskiego, [w:] Złotów nasz i wasz - materiały z seminarium 31 stycznia 2006 r., Złotów 2006.
} 
dla powiatów pilskiego i trzcianeckiego były znacznie niższe. Wyjątkiem była liczba zachorowań na dur brzuszny i odrę w powiecie trzcianeckim.

Przykładem obozu jenieckiego na terenie województwa poznańskiego może być jeden z małych obozów pracy w południowej części województwa - w Pudliszkach (powiat gostyński). Przetrzymywani tam Niemcy pracujący $w$ majątku rolnym Pudliszki zachorowali na przełomie stycznia i lutego 1946 r. na dur plamisty - tyfus. Choroba rozpoczęła się od dwóch przypadków wykrytych w połowie stycznia, by w początkach lutego objąć ponad połowę z dziewięćdziesięciu jeńców obozu. Z informacji lekarza powiatowego z Gostynia (ryc. 9.) wynika, że szybka izolacja obozu męskiego oraz szczepienia przeprowadzone wśród personelu medycznego i w obozie kobiecym zapobiegły rozprzestrzenieniu się epidemii ${ }^{18}$. Niemniej jednak, w tym powiecie, dzięki tak silnemu skupieniu ludności, odnotowano rekordową liczbę zachorowań na tę chorobę, która w skali roku dotyczyła siedemdziesięciu osób (por. dane $z$ tab. 1.). Śmierć $z$ tego powodu poniosło sześć osób (por. dane $z$ tab. 3.).

Oprócz transportów z jeńcami wywożonymi z obozów znajdujących się na ziemiach polskich przez ówczesne województwo poznańskie przejeżdżały transporty jeńców wojennych z ZSRR prowadzone przez NKWD. Jedna z największych epidemii tyfusu na tym terenie wybuchła w Zbąszyniu (powiat nowotomyski) w grudniu 1945 r. i styczniu roku następnego. Prawdopodobnie epidemię przywieziono $\mathrm{z}$ transportem jeńców wojennych przewożonych z ZSRR do rosyjskiej strefy okupacyjnej. Zachorowania z początku niezbyt liczne zaczęły się 13 grudnia od dwóch jeńców przeniesionych z transportu do aresztu Urzędu Bezpieczeństwa znajdującego się na samym dworcu PKP w Zbąszyniu. Byli to Paweł Richael i Paweł Bretzer, od których rozpoczęła się epidemia w areszcie UB - zachorowali przetrzymywani tam Jan Rolewski i Józef Kryś. Jak pisze w sprawozdaniu z 19 stycznia 1946 r. lekarz powiatowy z Nowego Tomyśla T. Skalski ${ }^{19}$, kierownictwo UB w Zbąszyniu nie wzywało do chorych lekarza, bo nie podejrzewało, że mogą być zakażeni tyfusem.

Równolegle w stojącym na stacji kolejowej przez trzy dni transporcie umierało codziennie do trzydziestu jeńców. Po kilku dniach chorych jeńców $\mathrm{z}$ aresztu przeniesiono do Szpitala Miejskiego, gdzie nie zdiagnozowano ich należycie. Gdy po paru dniach stracili słuch, lekarz z oddziału zakaźnego zorientował się, że są chorzy na tyfus. W międzyczasie choroba wymknęła się spod kontroli. W zestawieniach zachorowań widać, jakimi drogami zaczę-

18 APP, Urząd Wojewódzki Poznański w Poznaniu, sygn. 3236, k. 16.

19 APP, Prezydium Wojewódzkiej Rady Narodowej w Poznaniu, sygn. 3240, „Wykaz zachorowań i zgonów Mogilno - Nowy Tomyśl - Oborniki", k. 160, Sprawozdanie Lekarza Powiatowego z dnia 19 stycznia $1945 \mathrm{r}$. 


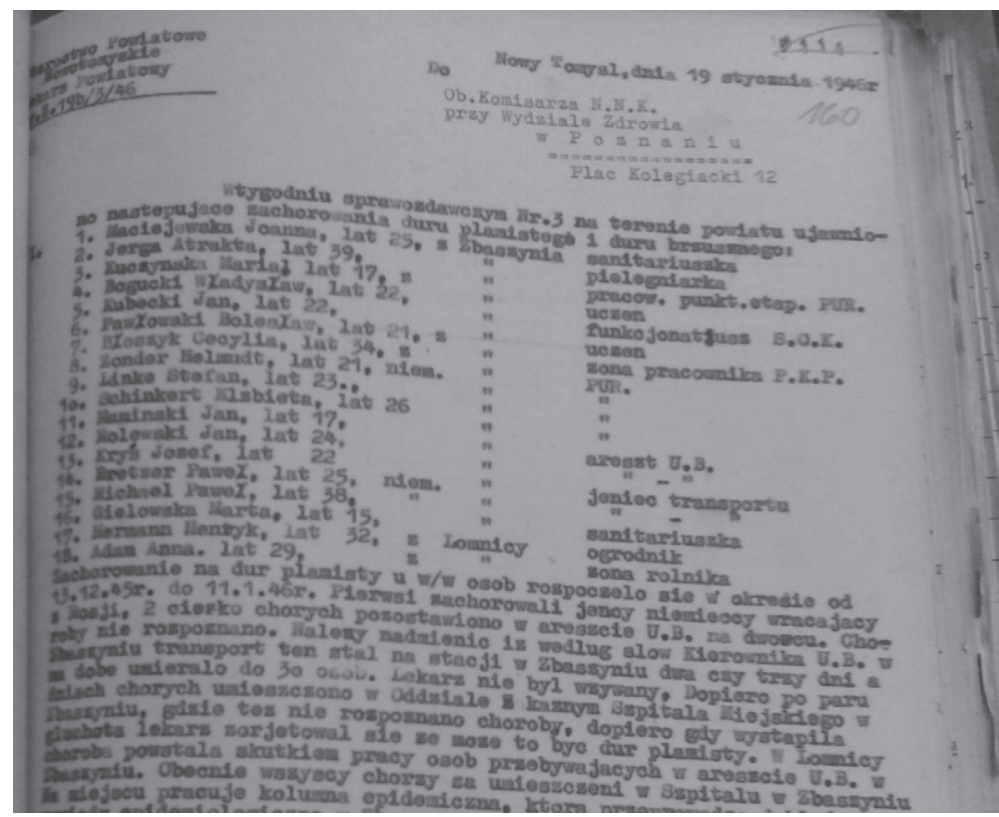

Ryc. 9. Sprawozdanie lekarza powiatowego z Nowego Tomyśla z 19 stycznia $1946 \mathrm{r}$.

Źródło: APP, Urząd Wojewódzki Poznański w Poznaniu, sygn. 3240, k. 160.

ła przenikać do miasta i jego okolic. W kolejnych tygodniach zakażenie wykryto u osób, które miały styczność z chorymi - dwóch sanitariuszek i pielęgniarki, pięciu pracowników punktu etapowego Państwowego Urzędu Repatriacyjnego w Zbąszyniu, a także funkcjonariusza Służby Ochrony Kolei i żony jednego z miejscowych kolejarzy. Poza miastem przypadki zachorowań na tyfus odnotowano w miejscowości Łomnica, w której znaleźli się byli więźniowie $z$ aresztu UB w Zbąszyniu.

Z Poznania skierowano do Zbąszynia i okolic specjalne kolumny epidemiologiczno-sanitarne do przeprowadzania dezynsekcji mieszkań, odzieży i bielizny. Poza tym wszystkie osoby, które miały kontakt z zarażonymi, poddano odwszawianiu i kąpieli w specjalnych środkach odkażających. Na koniec tej akcji przeprowadzono dezynsekcję samego dworca kolejowego w Zbąszyniu i jego okolic; jak pisze starosta powiatowy: „[...] teren dworca zwłaszcza tory - wyczyszczono i posypano wapnem" ${ }^{20}$. Równocześnie wprowadzono zarządzenie, by od tego momentu każdy transport z ludźmi jadący na zachód, czy będzie to transport repatriantów, czy jeńców, jeżeli przeby-

20 APP, Urząd Wojewódzki Poznański w Poznaniu, sygn. 3240, „Wykaz zachorowań i zgonów Mogilno - Nowy Tomyśl - Oborniki", k. 156-157, Sprawozdanie Starosty Powiatowego Nowotomyskiego z dnia 15 stycznia 1946 r. 
wać będzie na stacji w Zbąszyniu, zostanie poddany dezynfekcji. Natomiast te transporty repatriantów, które będą na tej stacji wyładowywane do dalszego rozwożenia po okolicy, muszą najpierw przejść podobną procedurę i okres kwarantanny, by następnie udać się do nowych miejsc zamieszkania ${ }^{21}$. W wyniku jednego zaniedbania odnotowano w ciągu całego roku 170 zachorowań na dur brzuszny (por. dane z tab. 1.), niemniej dzięki skutecznym działaniom epidemiologicznym, śmierć poniosły tylko cztery osoby.

\section{Obozy pracy dla obywateli polskich}

Obok miejsc, w których przetrzymywano jeńców wojennych i osoby narodowości niemieckiej oraz osoby wpisane na VD, istniała na terenie całego kraju sieć obozów pracy, w których przetrzymywano m.in. osoby skazane na karę pracy przymusowej przez delegatury Komisji Specjalnej do Walki z Nadużyciami Gospodarczymi i Spekulanctwem.

Autor monografii o tych obozach Bogusław Kopka doliczył się w Polsce ponad dwustu obozów pracy. Tylko w marcu 1947 r. przebywało w nich ponad osiemdziesiąt tys. osób ${ }^{22}$. W okolicach Poznania największy taki obóz znajdował się z Margoninie koło Rogoźna (powiat chodzieski). Z obozów tych nie przetrwało zbyt wiele materiału źródłowego dotyczącego zachorowań na choroby zakaźne. Niemniej jednak zestawienia danych ze sprawozdań o chorobach zakaźnych wskazują na liczne zachorowania na płonicę (143 przypadki w roku 1946) oraz płonicę (102 przypadki). Wykazano także 31 przypadków zachorowań na dur brzuszny.

Tab. 5. Więźniowie z wyrokami Komisji Specjalnej do Walki z Nadużyciami Gospodarczymi i Spekulanctwem

\begin{tabular}{|c|c|}
\hline Miesiąc i rok & Liczba uwięzionych w obozach \\
\hline IV 1946 & 9 \\
VI 1946 & 42 \\
XI 1946 & 414 \\
XI 1947 & 1189 \\
IV 1948 & 1616 \\
V 1949 & 1783 \\
XII 1951 & 581 \\
\hline
\end{tabular}

Źródło: T. Wolsza, dz. cyt.

21 Tamże, k. 157.

22 B. Kopka, Obozy pracy w Polsce 1944-1950. Przewodnik encyklopedyczny, Warszawa 2002. 


\section{Więzienia}

Województwo poznańskie w granicach z lat 1945-1950 było także miejscem, na terenie którego znajdowały się liczne więzienia, areszty śledcze i ośrodki specjalne Ministerstwa Bezpieczeństwa Publicznego. W latach 1945-1947 ze 123 zakładów karnych podległych MBP najwięcej zlokalizowanych było właśnie na terenie ówczesnego województwa poznańskiego - było ich aż 22. Wszystkie zakłady karne były ogromnie przepełnione. Tylko w więzieniu we Wronkach (powiat szamotulski), które przewidziane było na ok. 1800 więźniów, w grudniu 1948 r. przebywało ich ponad 3700. W tym samym czasie $\mathrm{w}$ więzieniu w Rawiczu (powiat rawicki) przetrzymywanych było ponad 3200 więźniów ${ }^{23}$. Dla powiatu szamotulskiego nie przesyłano danych o zapadalności na choroby zakaźnie w $1946 \mathrm{r}$. Zachorowalność w powiecie rawickim była nieco wyższa od poziomu przeciętnego tylko $\mathrm{w}$ odniesieniu do błonicy (144 przypadki). Zachorowania na pozostałe choroby zakaźne były $\mathrm{w}$ tym powiecie na poziomie niskim bądź przeciętnym.

Tab. 6. Zaludnienie zakładów karnych w latach 1945-1957

\begin{tabular}{|c|c|c|}
\hline Rok & Zaludnienie & $\begin{array}{c}\text { Więźniowie poli- } \\
\text { tyczni }\end{array}$ \\
\hline 1945 (1 IV) & 22785 & \\
1946 (1 XII) & 59772 & \\
1947 (1 III) & 67716 & \\
1948 (1 VII) & 67695 & \\
$1949(1 \mathrm{VII})$ & 103697 & \\
1950 (1 VI) & 95517 & 35177 \\
1951 (1 III) & 98506 & 34042 \\
1952 (1 XII) & 117380 & 33204 \\
1953 (1 VII) & 103187 & 30500 \\
1954 (1 XII) & 91197 & 20429 \\
1955 (1 I) & 89034 & 14849 \\
1956 (1 I) & 80920 & 2606 \\
1957 (do III) & 40715 & \\
\hline
\end{tabular}

Źródło: T. Wolsza, dz. cyt.

${ }^{23}$ T. Wolsza, dz. cyt. 


\section{Areszty Powiatowych Urzędów Bezpieczeństwa}

Kolejnymi miejscami, w których w tym okresie wbrew własnej woli pozostawała duża grupa obywateli, były Powiatowe Urzędy Bezpieczeństwa Publicznego. Każdy z nich posiadał własny areszt śledczy, w którym przetrzymywano zatrzymanych na czas tzw. śledztwa. Były to przede wszystkim pomieszczenia piwniczne zaadaptowane na cele więzienne. $\mathrm{W}$ dokumentach lekarzy powiatowych i komisji do walki z epidemiami znajdują się informacje o przypadkach chorób zakaźnych w tych miejscach. Ujawniane były wówczas, gdy aresztanci trafiali z aresztów śledczych UB do szpitali powiatowych z wyraźnymi objawami chorób zakaźnych. Przykładem może być informacja (patrz ryc. 2.), zachowana $w$ aktach Wydziału Zdrowia Urzędu Wojewódzkiego Poznańskiego z roku 1946. Z aresztu Powiatowego UB w Obornikach (powiat obornicki) trafiła do Szpitala Miejskiego Kazimiera Thierze. Funkcjonariusze starali się $\mathrm{w}$ takich wypadkach szybko izolować chorych, by nie dochodziło do wybuchu epidemii i by zabezpieczyć siebie przed zarażeniem zwłaszcza tyfusem ${ }^{24}$.

\section{Repatriacja}

Obok ruchu wojsk związanego z przesuwaniem się frontu na zachód, a następnie przemieszczaniem się wojsk na linię rzeki Odry i dalej w głąb Niemiec, już od połowy roku 1945 zaobserwować można było wzmożony ruch repatriacyjny obsługiwany na terenie ówczesnego województwa poznańskiego przez sieć punktów etapowych Państwowego Urzędu Repatriacyjnego. Na terenie województwa poznańskiego, które obejmowało także część ziemi lubuskiej z Gorzowem i Zieloną Górą, przez okres końca lat czterdziestych znajdowały się dwa ważne punkty etapowe, przez które przechodziły główne transporty z repatriantami ze wschodu - to Poznań i Zbąszyń. Z Poznania część transportów kierowana była na północ i północny zachód w kierunku Gorzowa, Piły i Szczecina. Te natomiast, które docierały do Zbąszynia, przez ten punkt kierowano na południe ziemi lubuskiej, m.in. do Zielonej Góry, Krosna Odrzańskiego oraz Żagania. Wraz z transportami repatriantów często podróżowały przywożone przez nich choroby.

Jak już powyżej zaznaczono, w zależności od podejścia w punktach etapowych i na stacjach, dokąd kierowano transporty kolejowe, łatwo było pominąć objawy chorób, które przywozili ze sobą repatrianci. Przykładem może być tu właśnie Zbąszyń (powiat nowotomyski) czy miejscowość Rościnno w gminie Skoki (powiat wągrowiecki), gdzie w maju 1945 r. osiedlono rodzinę repatriantów, w której sześć osób chorowało na dur plamisty - tyfus. Zmarła najstarsza z nich oraz jedna z dwóch pielęgniarek, które opiekowały

${ }^{24}$ APP, Urząd Wojewódzki Poznański w Poznaniu, sygn. 3241, k. 447. 
się tą rodziną. Przyczynę upatrywano w niewłaściwym rozpoznaniu choroby przez lekarza oraz braku higieny i zawszeniu ${ }^{25}$. Powtarzalność tego typu zdarzeń potwierdzają statystyki zachorowań w tych powiatach z $1946 \mathrm{r}$. Jak wspomniano wcześniej, powiat nowotomyski górował pod względem zachorowań na dur brzuszny i błonicę, a wągrowiecki na płonicę i błonicę.

\section{Oddziały Wojska Polskiego}

Poza zagrożeniami wynikającymi z przepływających przez Wielkopolskę transportów jeńców wojennych, repatriantów, wysiedlanych Niemców i VD, również stacjonujące na tym terenie jednostki wojskowe stawały się miejscami, w których dochodziło do wybuchów epidemii.

Jednym z takich ognisk stał się we wrześniu i październiku 1945 r. Gorzów Wielkopolski, w którym stacjonowały pododdziały 4. Pułku Artylerii Ciężkiej. Na tyfus plamisty zachorowało jedenastu oficerów i żołnierzy ${ }^{26}$. Sytuacja była bardzo poważna, bo przemieszczające się po tym terenie oddziały mogły stykać się w miejscowościach, do których się kierowały i gdzie miały docelowo stacjonować, z ogniskami chorób zakaźnych, a zwłaszcza z nosicielami najgroźniejszej z nich - tyfusu. Dowództwo Okręgu Wojskowego w Poznaniu wystąpiło do władz wojewódzkich z żądaniem, by wszystkie miejscowości, w których wystąpiły przypadki chorób zakaźnych, były przez służby epidemiologiczne oznaczane specjalnymi tablicami ustawianymi przy drogach do nich prowadzących. Wówczas kolumny wojskowe mogły stosować specjalne środki ostrożności $\mathrm{w}$ trakcie przemieszczania się pomiędzy garnizonami przez tereny będące ogniskami epidemii ${ }^{27}$. Zachowała się taka dokumentacja jedynie w dokumentach Wydziału Zdrowia Prezydium Miejskiej Rady Narodowej w Poznaniu, w postaci sporządzonego dla lat 1945-1955 zestawienia tabelarycznego zachorowań na główne choroby zakaźne.

\section{Podsumowanie i wnioski}

Punktem wyjścia do przeprowadzonych badań były informacje dostępne w Archiwum Państwowym w Poznaniu. Opisowe dane dotyczące występowania chorób zakaźnych na terenie województwa poznańskiego z 1945 r. po-

25 APP, Urząd Wojewódzki Poznański w Poznaniu, sygn. 3250, „Sprawy zwalczania duru plamistego", k. 31, Informacja Lekarza Powiatowego z powiatu wągrowieckiego z dnia 19 czerwca $1945 \mathrm{r}$.

${ }^{26}$ APP, Urząd Wojewódzki Poznański w Poznaniu, sygn. 3247, „Wykaz zachorowań i zgonów", k. 200-201.

27 APP, Urząd Wojewódzki Poznański w Poznaniu, sygn. 3250, „Sprawy zwalczania duru plamistego", k. 23. 
równano ze statystykami ilościowymi tego problemu dotyczącymi kolejnego roku. Na tej podstawie należy stwierdzić, że choć sytuacji epidemiologicznej w 1946 r. nie można uznać za stabilną, to jednak w zestawieniu z ostatnimi miesiącami 1945 r. odnotowano w tym zakresie na obszarze województwa poznańskiego znaczną poprawę.

$\mathrm{Na}$ podstawie szczegółowej analizy danych na poziomie powiatowym można wykazać związek pomiędzy bliskością dużych ośrodków miejskich i dróg kolejowych a liczbą zgłaszanych zachorowań na choroby zakaźne. Najwięcej przypadków chorób zakaźnych odnotowano w 1946 r. powiatach: konińskim, poznańskim, nowotomyskim, wągrowieckim i wolsztyńskim. Najmniejszą liczbę zachorowań spośród analizowanych powiatów odnotowano w powiatach: żnińskim, słubickim, międzyrzeckim.

W pierwszych miesiącach po wojnie wśród zgłoszonych zachorowań dominowały takie choroby zakaźne, jak: błonica, gruźlica, tyfus i płonica. Szczególnie dużo przypadków wystąpienia zakażeń odnotowano na obszarze powiatu poznańskiego oraz $\mathrm{w}$ powiatach zachodnich i północnych województwa. Natomiast najwięcej przypadków śmiertelnych odnotowano w odniesieniu do: gruźlicy, błonicy i duru brzusznego, z tym, że pierwsza $\mathrm{z}$ wymienionych chorób pochłonęła połowę wszystkich zgłoszonych przypadków śmiertelnych związanych z chorobami zakaźnymi.

Zarówno dur brzuszny, jak i plamisty okazały się chorobami typowo związanymi z okresem powojennym. W roku 1946 zachorowalność na nie stanowiła szesnaście proc. wszystkich zgłoszonych przypadków zachorowań, a śmiertelność sięgnęła trzynastu proc. wszystkich zgonów związanych z chorobami zakaźnymi. W latach pięćdziesiątych przypadków zachorowań na tę chorobę już nie odnotowano.

Duże znaczenie w 1946 r. miały także takie choroby, jak: błonica (42 proc. zgłoszonych zachorowań i 30 proc. zgonów) oraz gruźlica (16 proc. zgłoszonych zachorowań, 55 proc. zgonów). W 1953 r. błonica zmniejszyła zasięg i jej znaczenie epidemiologiczne spadło (siedem proc. zachorowań; sześć proc. zgonów). Niestety, skutki długoletniego przebiegu gruźlicy były odczuwalne w latach pięćdziesiątych. Mimo że stanowiła ona jedynie dziewięć proc. wszystkich zachorowań w 1953 r., to była główną przyczyną zgonów spowodowanych chorobami zakaźnymi. Niemniej jednak poziom śmiertelności na tę chorobę wyraźnie ograniczono.

O zupełnie odmiennej sytuacji można mówić w odniesieniu do choroby wirusowej oczu - jaglicy. W województwie poznańskim występowała ona przede wszystkim we wschodnich powiatach zarówno w latach czterdziestych, jak i pięćdziesiątych. Największe jej ognisko odnotowano w powiecie konińskim.

Podsumowując, porównanie danych z 1946 r. z danymi z 1953 r. pozwala zauważyć, że typowymi chorobami dla okresu wojny i tuż po nim okazały 
się: tyfus, gruźlica i dyfteryt. Typowa dla tego okresu była także niewystępująca jako jednostka chorobowa duża śmiertelność, związana z wyczerpaniem, brudem i niedożywieniem przemieszczających się mas ludności.

Uzyskane wyniki liczbowe dotyczące zapadalności na choroby zakaźne i związaną z nią śmiertelnością skonfrontowano z informacjami dotyczącymi wysiedleń, repatriacji, a także z rozmieszczeniem obozów pracy, obozów dla jeńców niemieckich, więzień i obozów pracy dla obywateli polskich oraz punktów etapowych PUR. W większości przypadków dane liczbowe pokrywały się ze zdarzeniami i zjawiskami, jakie miały miejsce $\mathrm{w}$ danym powiecie. Niemniej jednak na podstawie przeprowadzonych analiz wydaje się, że najsilniejszy związek można zaobserwować pomiędzy występowaniem chorób zakaźnych a umiejscowieniem obozów jenieckich i obozów pracy oraz strumieniem przepływającej przez punkty etapowe PUR ludności.

Przeprowadzone badania mogą być przykładem szerokiego wykorzystania informacji umieszczonych w dokumentach archiwalnych. Dane tego typu często wymagają specjalistycznego opracowania. Mogą one być zarówno źródłem informacji opisujących poszczególne zdarzenia historyczne, jak i stanowić podstawę do stworzenia historycznej bazy statystycznej w określonym obszarze.

\section{Bibliografia}

\section{Źródła archiwalne}

Archiwum Państwowe w Poznaniu - zespoły:

Urząd Wojewódzki Poznański 1945-1950;

Prezydium Wojewódzkiej Rady Narodowej w Poznaniu 1950-1975;

Prezydium Miejskiej Rady Narodowej w Poznaniu 1950-1956;

Państwowy Urząd Repatriacyjny - Oddział Wojewódzki w Poznaniu 1945-1951;

Archiwum Państwowe w Szczecinie - zespoły:

Państwowy Urząd Repatriacyjny w Szczecinie 1945-1951.

\section{Źródła drukowane}

Rozporządzenie Rady Ministrów z dnia 29 maja 1946 r. w sprawie tymczasowego podziału administracyjnego Ziem Odzyskanych, Dz.U. 1946, nr 28, poz. 177.

Ustawa z dnia 28 czerwca 1950 r. o zmianach podziału administracyjnego Państwa, Dz.U. 1950, nr 28, poz. 255.

\section{Literatura}

Cartwright Frederick F., Biddiss Michael, Niewidoczny wróg - zarazy i historia, przekł. M. Wyrwas-Wiśniewska, Warszawa 2005.

Kopka Bogusław, Obozy pracy w Polsce 1944-1950. Przewodnik encyklopedyczny, Warszawa 2002.

Mała encyklopedia zdrowia, pod red. J. Wolański, E. Rużyłło, Warszawa 1973.

Specłagier NKWD nr 2 w Poznaniu. Dokumenty, pod red. W. Handke, R. Kościański, G. Barczykowski, Poznań 2009. 
Stryjkowski Krzysztof, Poznań ‘45. Ostatni rok wojny i pierwszy rok odbudowy, Poznań 2013, s. 16-20 .

Szczegóła H., Przeobrażenia ustrojowo-społeczne na Ziemi Lubuskiej w latach 1945-1947, Poznań 1971.

Tworzenie się struktur aparatu bezpieczeństwa na terenie powiatu złotowskiego, [w:] Złotów nasz i wasz - materiaty z seminarium 31 stycznia 2006 r., Złotów 2006.

Wolsza Tadeusz, Obozy i inne miejsca odosobnienia na ziemiach polskich w latach 1944-1958, http:/ / klub-generalagrota.pl/kg/baza-wiedzy/referaty/624,dok.html (dostęp: 12 września 2013 r.).

Lucyna Błażejczyk-Majka, Jan Miłosz

\section{Występowanie chorób zakaźnych w Wielkopolsce w latach 1945-1953 w świetle dokumentów Archiwum Państwowego w Poznaniu}

\section{Streszczenie}

Wojna niesie ze sobą bezmiar cierpień, zniszczeń i śmierci. Ci którzy przeżyli musieli zmierzyć się z następującymi po niej chorobami.

W latach 40. i 50. lekarze powiatowi przekazywali do Wydziału Zdrowia Urzędu Wojewódzkiego w Poznaniu raporty dotyczące zachorowalności na choroby zakaźnie.

Artykuł oparty jest na prezentacji i porównaniu raportów z roku 1946 z analogicznymi raportami z $1953 \mathrm{r}$. Na tej podstawie podjęto próbę wyjaśnienia większej liczby zachorowań na choroby zakaźne na określonych obszarach Wielkopolski w kontekście historycznym tego okresu.

W odniesieniu do roku 1946 dane dotyczą 23 powiatów. Dane dla roku 1953 obejmują 26 powiatów. Ze względu na porównywalność informacji $\mathrm{w}$ artykule uwzględniono jedynie dane dla powiatów ziemskich.

Typowymi chorobami dla tego okresu okazały się: tyfus, gruźlica i dyfteryt, ale także dużą śmiertelność przypisać można wyczerpaniu, brudowi i niedożywieniu przemieszczających się wówczas mas ludności.

Z przeprowadzonych analiz wynika, że najsilniejszy związek występuje pomiędzy chorobami zakaźnymi a umiejscowieniem obozów jenieckich i obozów pracy oraz strumieniami ludności przepływającej przez punkty etapowe PUR. 


\title{
Incidence rate of infectious diseases in Greater Poland in the years 1945-1953 according to the documents of the National Archive in Poznan
}

\begin{abstract}
The war brings infinite suffering, death and destruction. Those who survive it have to deal with diseases that follow.

In the 1940s and 1950s, county doctors wrote reports on infectious disease incidence for the Department of Health of the Regional Government in Poznan.

The article comprises the presentation and comparison of parallel reports from the years 1946 and 1953. Based on that, it makes an attempt to explain the higher incidence rate of infectious diseases in some parts of Greater Poland based on the historical context of this period.

For the year 1946, the data describe 23 counties. Data for the year 1953 include 26 counties. Due to the comparability of information, the article includes data only for rural counties.

Typical diseases of the period were typhoid, tuberculosis and diphtheria, but the high mortality rate can also be explained by exhaustion, poor hygiene and malnutrition among the migrating masses of people.

The analyses conducted indicate that the strongest relationship can be observed between infectious diseases and the location of prisoners' and work camps and the migration of people going through the stage points of the National Repatriates Office.
\end{abstract}

